\title{
The K-Pg boundary section at Nasiłów, Poland: stratigraphic reassessment based on foraminifers, dinoflagellate cysts and palaeomagnetism
}

\author{
Zbyszek REMIN ${ }^{1, *}$, Michał CYGLICKI ${ }^{1,2}$, Marcin BARSKI ${ }^{1}$, Zofia DUBICKA ${ }^{1}$ \\ and Joanna ROSZKOWSKA-REMIN ${ }^{2}$ \\ 1 University of Warsaw, Faculty of Geology, Żwirki i Wigury 93, 02-089 Warszawa, Poland \\ 2 Polish Geological Institute - National Research Institute, Rakowiecka 4, 00-975 Warszawa, Poland
}

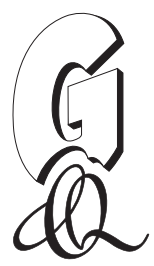

Remin, Z., Cyglicki, M., Barski, M., Dubicka, Z., Roszkowska-Remin, J., 2021. The K-Pg boundary section at Nasiłów, Poland: stratigraphic reassessment based on foraminifers, dinoflagellate cysts and palaeomagnetism. Geological Quarterly, 65: 45, doi: 10.7306/gq.1614

The Nasiłów section represents the uppermost part of the Middle Vistula River section, a classical Polish extra-Carpathian Cretaceous section, and gives access to the Cretaceous-Paleogene (K-Pg) boundary interval. Despite many papers that have been published so far, our newly collected data shed new light on the completeness of biostratigraphic and sedimentary records of the K-Pg at that site. The Nasiłów section encompasses the upper Maastrichtian regional XII and XIII foraminiferal assemblage zones and the lower Danian $\mathrm{P} 0$ ?-P $\alpha$ standard planktonic foraminiferal zones. The K-Pg boundary is placed at the top of a phosphatic layer. The grey marly chalk unit, never before subjected to examination of biostratigraphically important taxa, displays blooms of guembelitrids pointing to the uppermost Maastrichtian (XIII foraminiferal assemblage Zone) as well as of planktonic and benthic foraminifers of a reduced test size. Such foraminiferal dwarfism is commonly observed near the end of the Cretaceous and interpreted as a response to the Deccan volcanism (possible 2nd phase) that caused climate changes and ocean acidification. The terminal Maastrichtian age of the marly chalk unit is additionally supported by an acme of the dinoflagellate cyst Palinodinium grallator, together with Tallasiphora pelagica and Disphaerogena carposphaeropsis. The "Greensand", a distinct glauconite-quartz sand unit, contains exclusively terminal Maastrichtian planktonic foraminifers and dinoflagellate cyst assemblages. Individual specimens of Danian age are interpreted to be either an effect of contamination or were translocated down by burrowers into the Greensand. The lowermost portion of the Siwak (informal lithostratigraphic unit) demonstrates an early Danian age based on the co-occurrence of the common planktonic foraminifers Globoconusa daubjergensis, Guembelitria cretacea, Muricohedbergella monmouthensis, M. planispira, Planoheterohelix globulosa, Parvularuglobigerina extensa and Par. alabamensis. The last occurrence of Palynodinium grallator and the first occurrences of Carptella cornuta and Senoniasphaera inornata, recorded directly above the phosphatic layer, support the same age assignment. The new palaeomagnetic data cannot prove remagnetization at the boundary interval, in contrast to previous research which gave support to a hiatus in the critical interval.

Key words: K-Pg boundary, biostratigraphy, foraminifera, dinoflagellate cysts, palaeomagnetism, Nasiłów.

\section{INTRODUCTION}

The Nasiłów section, central Poland (Fig. 1) constitutes one of the classic K-Pg boundary sites of the central European epicratonic basin, providing insight into the possible nature of one of the largest and most severe mass extinctions in the history of life (e.g., Toon et al., 1997; Schulte et al., 2010). The abandoned quarry at Nasiłów gives access to $\sim 30 \mathrm{~m}$ of the upper Maastrichtian and Danian deposits, with the K-Pg boundary interval in the middle portion of the quarry (Fig. 2). The Kazimierz Opoka - an informal lithostratigraphic unit of the late Maastrichtian age is mainly composed of opoka (= siliceous chalk/limestone with biogenic silica). The Siwak - another infor-

\footnotetext{
* Corresponding author, e-mail: zremin@uw.edu.pl
}

Received: April 29, 2021; accepted: August 19, 2021; first published online: September 13, 2021 mal lithostratigraphic unit of the early Danian age is represented by gaize (= siliceous limestone with detrical quartz, glauconite and clay). Both units are separated by distinct glauconitic quartz sand unit - the Greensand (Fig. 2).

During decades of research on sedimentology (Pożaryska, 1952; Krach, 1981; Machalski and Walaszczyk, 1987; Hansen et al., 1989; Machalski, 1998), magnetostratigraphy (Hansen et al., 1989), and the palaeontology of different fossils such as foraminifers (Pożaryska, 1965; Żarski et al., 1998), sponges (Świerczewska-Gładysz and Olszewska-Nejbert, 2006), dinoflagellate cysts (Hansen et al., 1989), belemnites (Keutgen et al., 2017), bivalves, gastropods and ammonites (Krach, 1981; Abdel-Gawad, 1986; Machalski and Walaszczyk, 1987, 1988; Machalski, 1998, 2005a, b, 2012) and echinoids (Machalski and Jagt, 2018), the position of the K-Pg boundary at Nasiłów has been variously interpreted and placed at different levels within the boundary interval. It was drawn at the top of the Kazimierz Opoka unit (Pożaryska, 1965, 1967; Krach, 1974, 1981; Błaszkiewicz, 1980; Hansen et al., 1989; Machalski, 1998; Świerczewska-Gładysz and Olszewska-Nejbert, 2006; 


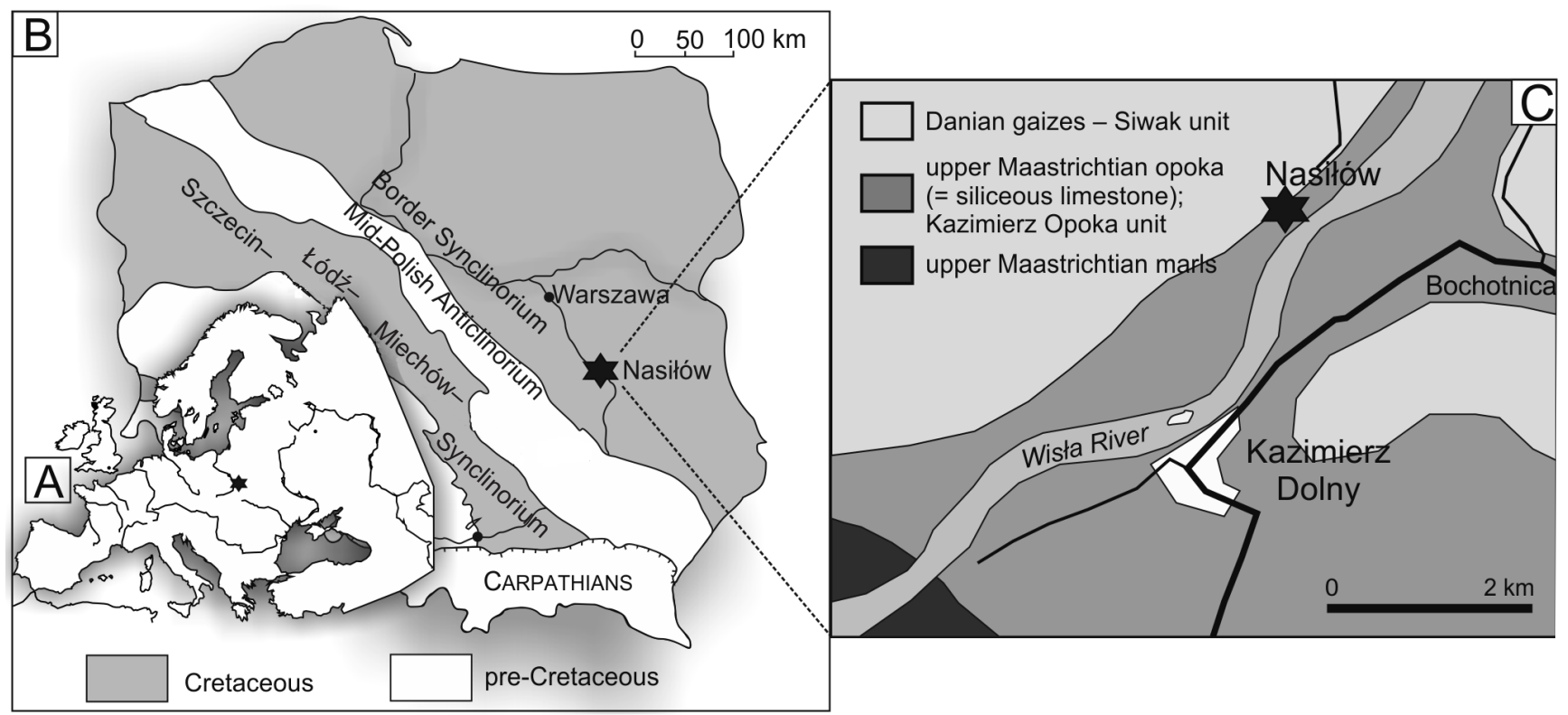

Fig. 1A - location of the K-Pg site at Nasiłów in Europe; B - Poland with the extent of the Upper Cretaceous deposits in extra-Carpathian Poland (after Pożaryski, 1974, simplified); C - simplified geological sketch map of the Nasiłów and Kazimierz Dolny area (after Pożaryska, 1952, simplified)

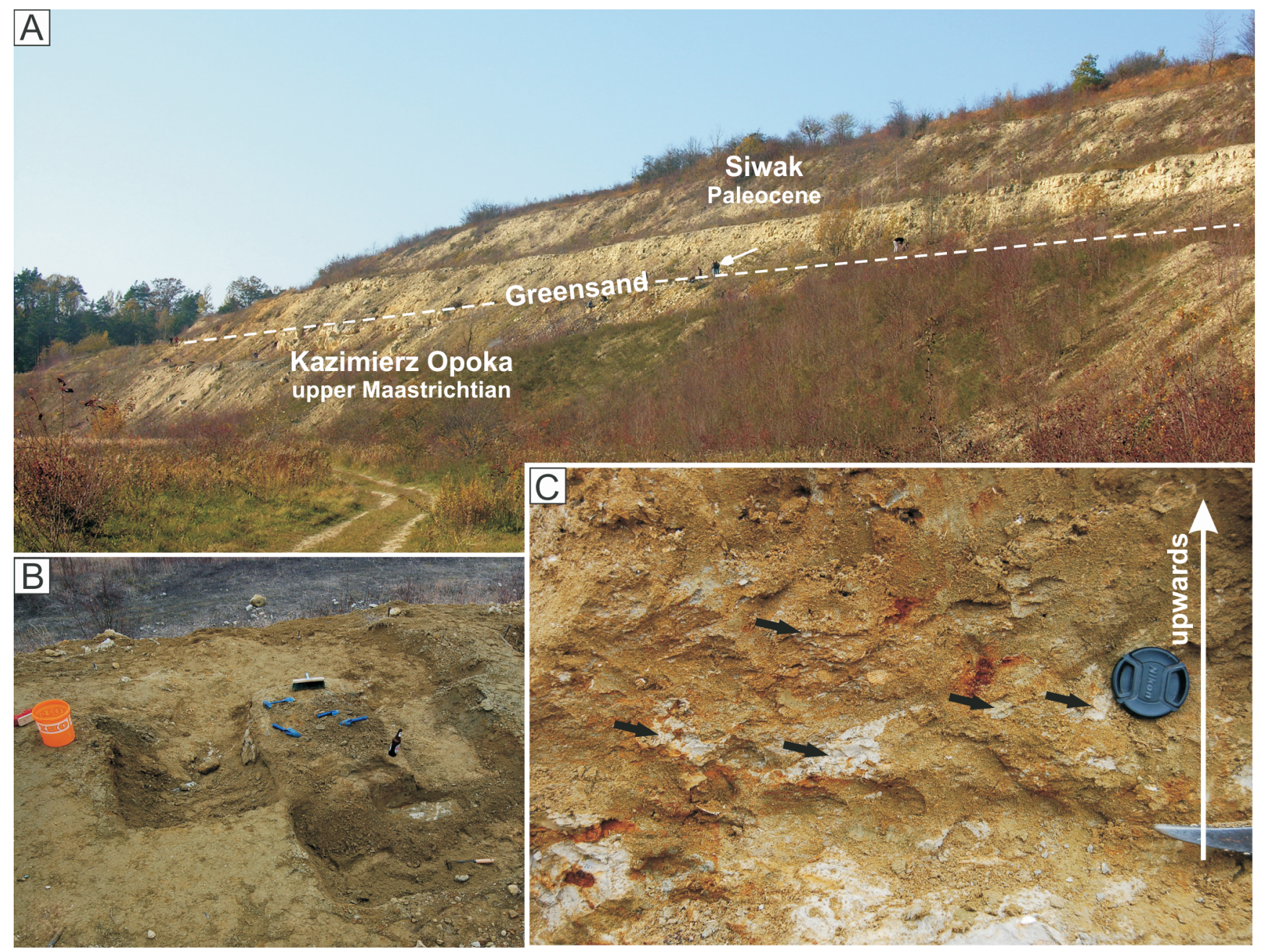

Fig. 2A - general view of the Nasiłów Quarry showing the Kazimierz Opoka at the base, Greensand in the middle and the Siwak unit at the top, the arrow indicates people for scale; B - Greensand divided into $1 \mathrm{~m}^{2}$ fields for detailed examination for different purposes, 10 -litre bucket for scale; $\mathrm{C}$ - details of the lower portion of the Greensand, black arrows indicate fragments and shards representing the remnants of the marly chalk [unit III] 
Machalski and Jagt, 2018), at the base of the phosphatic layer (Machalski and Walaszczyk, 1987), at the top of the phosphatic layer (Radwański, 1985, 1996; Abdel-Gawad, 1986) or above the phosphatic layer within the gaize part of the Siwak unit (Kongiel, 1935; Pożaryski, 1938; Putzer, 1942). Based on various data and assumptions, several sedimentological scenarios have been proposed (e.g., Pożaryska, 1952, 1965; Krach, 1974, 1981; Machalski and Walaszczyk, 1987; Hansen et al., 1989; Machalski, 1998; Świerczewska-Gładysz and Olszewska-Nejbert, 2006; Machalski and Jagt, 2018).

The faunal data, especially those supporting the Danian age of the Greensand (e.g., Pożaryska, 1965; Krach, 1974, 1981; Żarski et al., 1998; Machalski, 1998, 2005a, b; Świerczewska-Gładysz and Olszewska-Nejbert, 2006; Machalski et al., 2016; Machalski and Jagt, 2018), in addition to the palaeomagnetic data of Hansen et al. (1989), were critical to the interpretations and to placing the K-Pg boundary, by many authors, at the top of the Kazimierz Opoka unit terminated by the intensely burrowed hardened limestone. This implies a considerable hiatus spanning the latest Maastrichtian and the earliest Danian (for discussion, compare Hansen et al., 1989; Machalski, 1998, 2005a; Machalski and Jagt, 2018). Such a stratigraphic interpretation resulted in the developing of a complex sedimentary model across the K-Pg boundary at Nasiłów, including exhumation, erosion, omission, reworking, and phosphatization events (compare e.g., Hansen et al., 1989; Żarski et al., 1998; Machalski, 1998, 2005a, b; ŚwierczewskaGładysz and Olszewska-Nejbert, 2006; Racki et al., 2011; Machalski et al., 2016; Machalski and Jagt, 2018). By contrast, Radwański (1985), Abdel-Gawad (1986), and Machalski and Walaszczyk (1987) considered that the Greensand is latest Cretaceous in age.

The emerging discrepancies in defining the age of the Greensand between particular authors were caused by the fact that either Maastrichtian or Paleocene faunal elements were considered to be of primary importance in the final conclusions. Consequently, the Danian/Montian interpretation of the age of the Greensand assumed the redeposited character of the latest Maastrichtian fauna into this unit. Accordingly, depending on what age is interpreted for the Greensand for whatever reasons, a different sedimentological model would be adopted as a consequence.

Considering the above age-discrepancies, the aim of our studies was to develop a revised stratigraphic scheme for the Nasiłów succession integrating both biostratigraphic (macrofossils, foraminifers, and dinoflagellate cysts) and palaeomagnetic (magnetostratigraphic) data. Special attention is paid to a precise age-assignment for the marly chalk [unit III], deposits never previously subjected to examination of biostratigraphically important forms, as well as to the Greensand. The age interpretation of particular units within the boundary succession is a prerequisite for the proper understanding of the set of processes active during the K-Pg times at Nasiłów and, in consequence, to proposing a reliable sedimentological scenario. Our approach shows that the Nasiłów succession is much more complete than hitherto thought, most likely with only the P0 foraminiferal zone missing, thus constituting one of the most complete $\mathrm{K}-\mathrm{Pg}$ sections in this part of Europe.

\section{GEOLOGICAL SETTING}

The Nasiłów section is situated at the left bank of the Wisła River, central Poland, opposite the town of Kazimierz Dolny. The section is located within the Border Synclinorium, NE of the Mid-Polish Anticlinorium (Fig. 1), which is interpreted as the in- verted part of a former Danish-Polish Trough (e.g., Pożaryski, 1974).

The exposed succession is here subdivided into six units labeled I to VI (Fig. 3). Unit I corresponds to the Kazimierz Opoka (Figs. 2A and 3), an upper Maastrichtian informal lithostratigraphic unit which is composed of opoka with $\sim 65-70 \%$ of $\mathrm{CaCO}_{3}$ and occasional marly intercalations. It is terminated by a $0.5-1.0 \mathrm{~m}$ thick intensely burrowed yellowish hardened limestone [unit II] (Fig. 3), which constitute a well-developed incipient hardground (understood according to Kennedy and Garrison, 1975). The upper, uneven surface of the hardened limestone is overlain by a non-indurated, soft, white-grey marly chalk [unit III]. The burrows penetrate both the marly chalk and the hardened limestone usually to $\sim 30-40 \mathrm{~cm}$ down, however, this feature can vary markedly. In the marly chalk, the $\mathrm{CaCO}_{3}$ content slightly decreases by comparison with the Kazimierz Opoka unit to $\sim 58 \%$ (Fig. 3).

Higher up in the section, there is a distinct, $20-50 \mathrm{~cm}$-thick glauconitic quartz sand unit [unit IV] - Greensand (Figs. 2 and 3). The Greensand represents an easily recognizable sedimentological unit within the K-Pg interval. This unit is traceable across the entire Nasiłów Quarry over a distance of $\sim 400-500 \mathrm{~m}$, in addition to being present in a nearby escarpment of the Wisła River (e.g., at Bochotnica and Kamienny Dół, $2 \mathrm{~km}$ distant coeval K-Pg sections). The Greensand is predominantly composed of angular quartz grains, glauconite, and microfossil tests in a marly matrix. By comparison with units II and III, the $\mathrm{CaCO}_{3}$ decreases sharply to $\sim 15 \%$, whereas the amounts of glauconite, quartz, and clay minerals increase to $\sim 85 \%$. Such contents of particular ingredients are characteristic of the whole Greensand unit (Fig. 3). The grain-size distribution within the Greensand is uniform and does not show any trend either down- or upwards.

Shards of marly chalk, thus of lithology corresponding to unit III (Figs. 2C and 3), are a significant component of the Greensand, being usually angular in shape. The largest fragments, up to $15 \mathrm{~cm}$, are concentrated in the lower portion of the Greensand, whereas the smallest, centimeter-sized or smaller, occur up to the top of the unit, marked by the phosphatic layer (Fig. 3). No marly shards were noted above the phosphatic layer. Additionally, well-rounded quartz pebbles, up to $2.5 \mathrm{~cm}$ across, although rare, were collected mainly from the lower portion of this unit.

The fauna of the Greensand is rich and diverse; however, it is variously preserved, with some of the forms being filled with opoka/marly-chalk-like sediment not corresponding to the host lithology of the Greensand. Although much of the fauna is fragmentarily preserved, including the most prominent component, belemnites, some very well fossilized brachiopods with complete brachidia and belemnites with thin and delicate alveolar walls were also noted within this unit.

The top of Greensand is marked by a $\sim 5-10 \mathrm{~cm}$ thick phosphatic layer [unit V] (Fig. 3). It is composed mainly of phosphatic fragments of sponges, not infrequently showing angular shapes and sharp edges. While the lower boundary of the phosphatic layer is somewhat diffuse into the underlying Greensand, the upper boundary is rather sharp; however, this can change from place to place.

The "iridium layer" has not yet been recognized in the Nasiłów section, although the presence of iridium fall-out is indicated by a small enrichment in Ir-PI and rare earth elements (= REEs) detected within the Greensand both at Nasiłow and the coeval section at Bochotnica (Hansen et al., 1989).

The Greensand [unit IV] together with a phosphatic layer [unit V] is overlain by the Siwak unit [VI] - the Danian informal lithostratigraphic unit, which is represented by gaizes with distinct beds of limestone (Fig. 3). Just above the phosphatic layer 


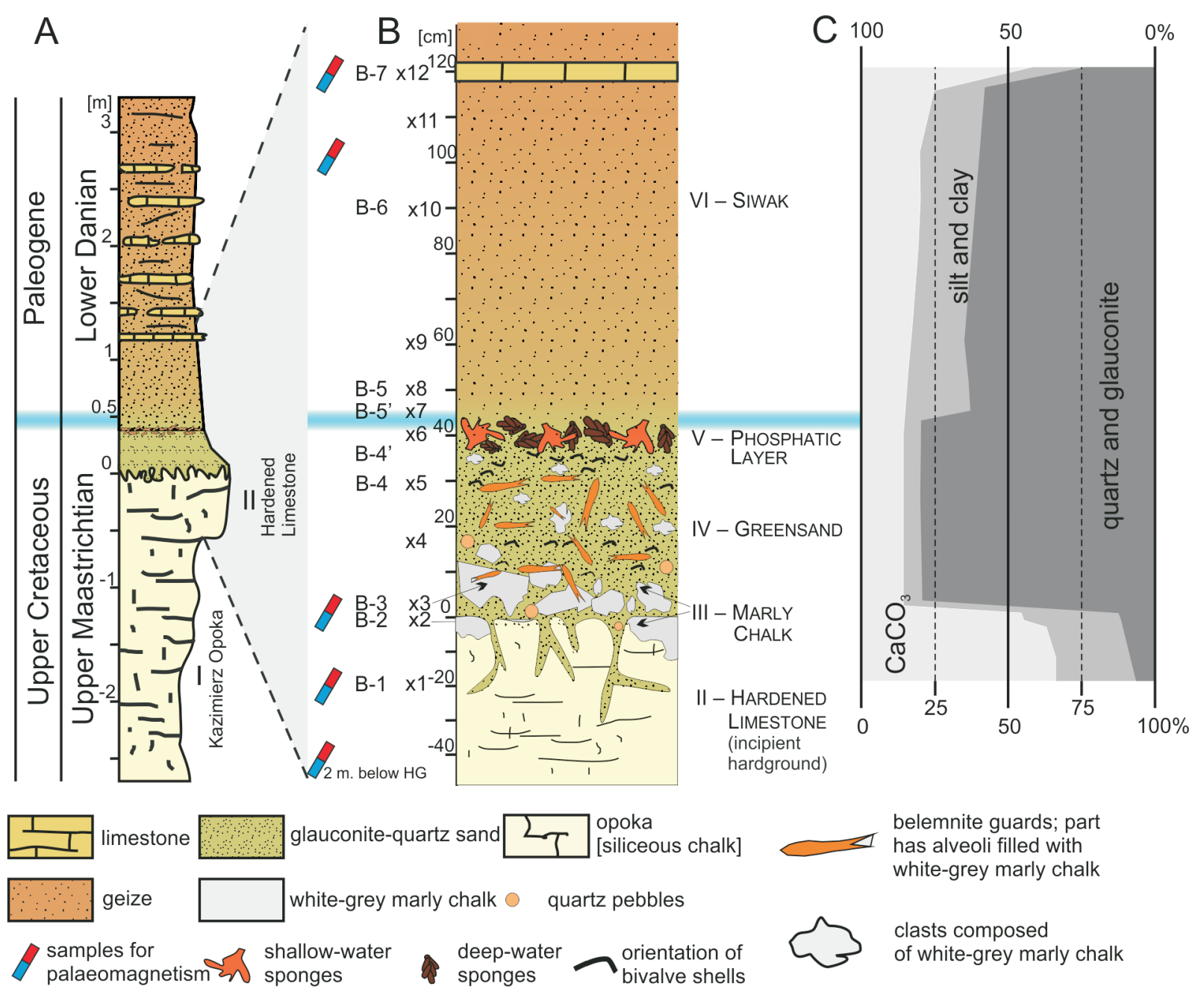

Fig. 3. Details of the study section at Nasiłów

A - generalized section of the boundary interval; B - cm-scale detailed lithological log of the K-Pg interval, samples for dinoflagellate cysts are labeled by B-prefix, samples for foraminifers are labeled with x-prefix, magnets - samples for palaeomagnetism;

C - percentage amount of selected components

(= in the lowermost Siwak unit), a distinct decrease in quartz and glauconite content by $\sim 20 \%$ is observed together with an increase in silt and clay content by a similar amount (Fig. 3). The $\mathrm{CaCO}_{3}$ content starts to slowly and gradually increase from $\sim 15 \%$ in the phosphatic layer to $24 \%$ just below the first limestone layer, $\sim 1 \mathrm{~m}$ above; in the first limestone layer the $\mathrm{CaCO}_{3}$ content increases markedly to $\sim 55-60 \%$ (Fig. 3). Within this interval, i.e. from the phosphatic layer to the first limestone bed in the Siwak unit, small cm-size phosphorites have also been detected (e.g., Machalski, 1998).

\section{FORMER STUDIES}

Pożaryska (1965) gave the first stratigraphic account based on foraminifera around the K-Pg boundary. Based on the borehole material, three subsurface formations were distinguished by her, i.e. the "Żyrzyn Beds" (upper Maastrichtian), the "Sochaczew Beds" and the "Puławy Beds" (Danian). Pożaryska correlated the Greensand at Nasiłów with the subsurface "Sochaczew Beds. The presence of opoka/chalk-like shards within the Greensand was assumed to represent a previously present, now eroded away, uppermost Maastrichtian unit assigned by her to the "Żyrzyn Beds".

Non-cephalopod macrofauna from around the K-Pg interval at Nasiłów and nearby localities were studied by Krach (1974, 1981). He noted the allochthonous character of the Cretaceous faunal assemblage from the basal glauconitic sandstone with phosphorites, represented by mixed macrofossils coming from different biotopes chaotically distributed within the glauconitic sand, with part of the fauna coming from sublittoral environments, whereas other faunal items were transported from the deeper part of the basin. Similarly to Pożaryska (1965), Krach assumed a Paleocene age for the Greensand and additionally combined the Greensand and overlying Siwak into one transgressive depositional cycle.

Radwański $(1985,1996)$ based on the occurrence of typical Maastrichtian cephalopods, i.e. Scaphites constrictus, to the very top of the hardground and Belemnella kazimiroviensis to the top of the phosphatic layer, placed the K-Pg boundary at the top of the latter unit.

Abdel-Gawad (1986) provided an additional comparative study of non-cephalopod molluscs (scaphopods, gastropods, and bivalves) of the Middle Vistula Valley, in addition to recon- 
structing the depositional environment during the Late Cretaceous and the $\mathrm{K}-\mathrm{Pg}$ transition.

Machalski and Walaszczyk (1987) recognized three groups of fossils within the Greensand, i.e. (1) phosphatized Maastrichtian, (2) unphosphatized Maastrichtian, and (3) a Danian assemblage. The upper Maastrichtian fossils infilled by glauconitic sandstone as well as those in a very good state of preservation were considered as indigenous. The Danian assemblage was found to be unevenly distributed within the Greensand with the majority of specimens reported from the phosphatic layer (cf. Fig. 3), and only a few, mainly burrowing Nucula and Cucullaea, beneath. Machalski and Walaszczyk (1987) proposed four stages of Greensand formation: (1) hardground formation followed by subsequent deposition of the Greensand and the additional carbonate unit; (2) a halt in deposition, early cementation along with the activity of burrowers (stages 1 and 2 are latest Maastrichtian); (3) erosion of the carbonate unit and formation of a residual lag (expressed as the phosphatic layer) along with phosphatization dated to the early and/or middle Danian; (4) deposition of the gaizes of the Siwak unit coupled with mottling of the sediment by infaunal activity leading to intense bioturbation of the Greensand during late Danian time. The spotty and patchy occurrence of the Danian fossils together with mainly burrowing bivalves below the phosphatic layer was thought to prove their secondary introduction into the Greensand by infaunal activity. Accordingly, based on these overall characteristics, the K-Pg boundary was placed at the top of the Greensand and, to be precise, at the base of the phosphatic layer.

Hansen et al. (1989) provided the first dinoflagellate cyst studies from the Nasiłów section and assigned the hardened limestone (the incipient hardground) [unit II] to the Palinodinium grallator Zone of lower albeit not lowermost Maastrichtian age due to the lack of the latest Maastrichtian species Thalasiphora pelagica. The basal Siwak unit (= above the phosphatic layer) was considered to be of early albeit not lowermost Danian age and was tentatively correlated with the interval $\sim 10 \mathrm{~m}$ above the K-Pg boundary in the Dania Quarry (Denmark). He argued for remagnetization from the $30 \mathrm{~N}$ to $29 \mathrm{R}$ palaeomagnetic chron just above the phosphatic layer. Trace element studies showed a small iridium enrichment in the Greensand in both the Nasiłów and neighbouring Bochotnica sections. He suggested that dissolution was responsible for removing previously present units (now gone): i.e. glauconitic chalk (proved by fossil infillings), the $\mathrm{K}-\mathrm{Pg}$ beds, in addition to an equivalent of the Danish Cerithium Limestone of earliest Danian age. The former presence of the latter unit, has been postulated based on belemnite alveoli infills similar to the original Cerithium Limestone. Hence a considerable hiatus was suggested for the K-Pg beds at Nasiłów.

Żarski et al. (1998), based on foraminiferal and macrofaunal evidence, quoted a Danian age for the Greensand and the overlying Siwak unit from the Kamienny Dół locality (a coeval $\mathrm{K}-\mathrm{Pg}$ site in the Nasiłów area). They also reported several soft and hard limestone clasts within the Greensand layer.

Machalski (1998) proposed a reconstruction of the depositional history at the K-Pg transition at Bochotnica and Nasiłów based on a detailed taphonomic analysis and questioned the presence of a late Maastrichtian hardground at the top of the Kazimierz Opoka. Three fossil assemblages within the Greensand and overlying phosphatic layer were distinguished, being characterized by macrofossils of the Maastrichtian, Paleocene, and unknown ages. The Maastrichtian fossils with attached pieces of soft opoka (belemnites, bivalves) were recorded solely from below the phosphatic layer.
The majority of the supposed Paleocene fauna came from around the phosphatic layer and upwards in the section, besides deep-burrowing bivalves of the genera Nucula and Cucullaea.

The sedimentological scenario proposed by Machalski (1998; very similar to that of Hansen et al., 1989), assumed the deposition of: (1) siliceous limestone (= opoka); (2) slightly glauconitic carbonate mud (upper Maastrichtian); (3) a K-Pg clay layer enriched in Ir; (4) the equivalent of the early Danian Cerithium Limestone known from Denmark and elsewhere; (5) an erosional episode during the Danian, leading to the destruction of units 2-4 together with the upper part of the opoka (1). In such a scenario, the burrowing event took place already in the Danian, being preceded by exhumation of older deposits, its subsequent erosion, deposition of glauconitic sand (= Greensand) and formation of the residual lag, currently expressed as a phosphatic layer. Burrowing activity on the sea-floor, combined with a slow sedimentation rate of the Greensand which fills the burrows, resulted in the formation of the "pseudo-breccia" at the top of the Kazimierz Opoka unit (cf. also Machalski and Walaszczyk, 1987) formed in a manner proposed initially by Kennedy and Garrison (1975). The presence of supposedly mixed Maastrichtian and Danian faunal assemblages and the assumed lack of in situ Maastrichtian fossils within the Greensand layer, led to the conclusion that the Greensand should entirely be interpreted to represent the basal, transgressive depositional cycle of an early, albeit not earliest Danian age (cf. also Hansen et al., 1989). Consequently, the $\mathrm{K}-\mathrm{Pg}$ boundary has been placed at the junction of the Kazimierz Opoka and Greensand.

Świerczewska-Gładysz and Olszewska-Nejbert (2006) reported two sponge assemblages from the Greensand and overlying phosphatic layer. Out of 26 sponge species, 12 turn out to be unknown from the underlying Kazimierz Opoka. Surprisingly, all the sponge forms recognized turn out to be solely Maastrichtian. Based on two different sponge assemblages mixed within the phosphatic layer, an additional latest Maastrichtian stage of erosion was proposed.

Keutgen et al. (2017) analysed belemnites of the Belemnella kazimiroviensis group. He found no differences in the communities from the Kazimierz Opoka and the overlying Greensand. Most of the belemnites were found to be redeposited from the upper Maastrichtian deposits formerly present, now gone, at Nasiłów or around this site. Of note is the record of an ammonite Hoploscaphites constrictus cf. crassus found in the Greensand, preserved as an impression on a reworked pycnodontid oyster shell, suggesting that erosion must have cut down into deposits older than the uppermost Maastrichtian.

Machalski and Jagt (2018) analysed members of three echinoid assemblages occurring together in the Greensand in the Kazimierz Dolny area. The assemblages were characterized by different stages of preservation (phosphatized and unphosphatized) and different ages: (1) late Maastrichtian, (2) presumably early Danian, and (3) probably younger, middle to late Danian. They considered the Greensand as a condensed, transgressive unit with mixed faunas of different ages and provenance. Additionally, those authors discredited the presence in the Nasiłów area of an equivalent of the Danian Cerithium Limestone, postulated to be formerly present and now gone (cf. Hansen et al., 1989; Machalski, 1998). This was based on the fact that all the phosphatized moulds of echinoids interpreted as Danian in age are composed of phosphatized glauconitic sandstone, which is markedly different from the classic Cerithium Limestone. 


\section{MATERIALS AND METHODS}

Foraminiferal and dinoflagellate cyst biostratigraphy, as well as palaeomagnetic measurements, have been studied across the K-Pg interval of the Nasiłów section.

Palaeomagnetism. For palaeomagnetic studies, 20 core samples and four hand samples were collected from 5 sample sites studied (for precise locations within the section see Fig. 3). From each sample, a minimum of 2 specimens were cut and all specimens were analysed in the Geophysical Laboratory of the Polish Geological Institute - National Research Institute. The NRM measurements and demagnetization experiments were carried in a magnetically shielded space (a low-field cage, Magnetic Measurements, UK, which reduces the ambient geomagnetic field by $\sim 95 \%$ ). Natural remnant magnetization (NRM) and magnetization during the demagnetization procedures were measured on a JR-6A dual-speed spinner magnetometer (AGICO, Brno). After natural remnant magnetization (NRM) measurements, both alternating field demagnetization (AFD) and thermal demagnetization (THD) were applied. The AFD demagnetization procedure was carried out from 5 to $100 \mathrm{mT}$, in $5 \mathrm{mT}$ steps, using a shielded demagnetizer (MOLSPIN, UK). The thermal demagnetization procedure was carrid out from 100 to $500^{\circ} \mathrm{C}$ in $50^{\circ} \mathrm{C}$ steps. Samples were heated using a non-magnetic oven MMTD1 thermal demagnetizer (Magnetic Measurements, UK). After each step of THD, the magnetic susceptibility (MS) was measured to control and detect potential thermo-magnetic changes in the rocks. Magnetic susceptibility was monitored with a KLY-2 bridge (AGICO, Brno). For analysis of components of magnetization, RemaSoft software (AGICO, Brno) was used.

Sampling procedure for the microfossils. Due to the nature of the exposure of the K-Pg boundary interval at Nasiłów and the ease of contaminating the samples with material falling from above, a special procedure was applied to avoid risk of contamination of material rich in e.g. Danian foraminifers. This was especially important in sampling from the Greensand since its age is of crucial importance. When taking subsequent samples, we placed a special construction separating the profile from the environment to prevent accidental contamination. During this procedure, disposable tools were used; i.e., each touch of the profile or ground by the tool resulted in the need to take a new tool. Both clean tools and bags were kept locked up without contact with the ground or section. The collected samples were packed into double bags. Before being opened in the laboratory, they were washed before the contents were further processed.

Foraminifers. Twelve samples (labeled $x 1$ to $x 12$ ) were analysed for foraminifers. Washed residues were obtained by using the liquid nitrogen method (Remin et al., 2012) and then washed under running water through a $>70 \mu \mathrm{m}$ sieve. Quantitative analysis of benthic foraminiferal assemblages has been conducted for sample $\times 3$ based on 250 specimens picked from a representative split. Foraminifers are abundant and well-preserved in all of the other lithological units studied as well as in the Greensand. In order to avoid any doubts as to the quality and purity of the samples collected, an additional set of samples (12 samples) was taken from the central part of the Nasiłów quarry, $\sim 200 \mathrm{~m}$ from the first location, in accordance with the procedure described above.

Dinoflagellate cysts. For dinoflagellate cysts, 9 palynological samples (labeled B1-B4, B4'-B5', B5-B7) have been analysed. Each of the 50-gram-samples was treated with $37 \%$ $\mathrm{HCl}$ and $40 \% \mathrm{HF}$ to remove carbonates and silicate minerals. Finally, the organic residue was neutralized on a 15 micrometer diameter sieve and condensed by heavy liquid $\left(\mathrm{ZnCl}_{2}, 2 \mathrm{~g} / \mathrm{cm}^{3}\right)$ separation. The palynological assemblages are characterized by good preservation. Two slides per sample were examined. In most cases, palynomorphs were counted up to 300 specimens per sample. Microphotographs were taken using a Nikon Eclipse E-600 microscope equipped with phase contrast and a digital camera.

\section{RESULTS}

\section{MAGNETOSTRATIGRAPHY}

Almost all specimens (Fig. 3) were characterized by very low natural remnant magnetization (NRM) ranging from 30 to $100 \times 10^{-6} \mathrm{~A} / \mathrm{m}$ and magnetic susceptibility values in a range from 18 to $68 \times 10^{-6} \mathrm{SI}$.

Alternating field demagnetization brought no important magnetization decrease. This indicates that the high-coercivity component predominates in the rocks analysed (an example of this behavior is shown on Fig. 4B). During thermal demagnetization, in $40 \%$ of the specimens, a rapid decrease in NRM occurred between 100 and $150^{\circ} \mathrm{C}$ which, together with weak magnetization and high-coercivity magnetic behavior, might indicate the presence of goethite. In $60 \%$ of the specimens, stepwise demagnetization brought random changes in the magnetic intensities of specimens and directions (for example see Fig. 4D). A rapid increase in intensities was observed above $300^{\circ} \mathrm{C}$. Also, magnetic susceptibility increased after heating at $350^{\circ} \mathrm{C}$ (Fig. 4E) and samples changed their colour from white-yellow to red. This indicated the generation of new magnetic phases corresponding probably to the transformation of goethite to hematite (e.g., Dekkers, 1988).

Only two specimens - N01.1 and N04.1 (Fig. 4A, C) - behaved stably during demagnetization up to $500^{\circ} \mathrm{C}$. The stepwise acquisition of the isothermal remnant magnetization (IRM) and thermal demagnetization of a composite IRMs acquired along 3 perpendicular axes (Lowrie, 1990) indicates that the magnetic signal is controlled by low-coercivity magnetic minerals (probably magnetite).

The characteristic remnant magnetization (ChRM) calculated in both specimens from the range from 100 to $300^{\circ} \mathrm{C}$ shows shallow negative inclinations and declination (Fig. 4A, C). However, these values are different from the ones expected Cretaceous and Paleogene directions (D/I=8/60 for normal and $\mathrm{D} / \mathrm{l}=187 /-58$ for reversed polarity; e.g., Plasota et al., 2015) and cannot be interpreted as a primary undisturbed component. Furthermore, the directions and magnetic characteristics obtained are unrepeatable in other specimens, even in those cut from the same sample.

\section{BIOSTRATIGRAPHY}

The chronostratigraphy of particular units is based here solely on biostratigraphically important groups, i.e. foraminifers, dinoflagellate cysts, belemnites, and ammonites (Fig. 5).

In all of the samples studied, foraminifers are abundant with good test preservation; however, in the Greensand they are less frequent and often have broken or incomplete tests. The two sets of samples chosen for the foraminiferal studies gave almost equivalent results, as regards both qualitative and quantitative output; therefore, these results were summed and are shown as set $x 1-x 12$ in all the figures. Selected foraminiferal species are shown in Figures 6 and 7. In most of the samples, dinoflagellate cysts are abundant and quite diverse, showing 

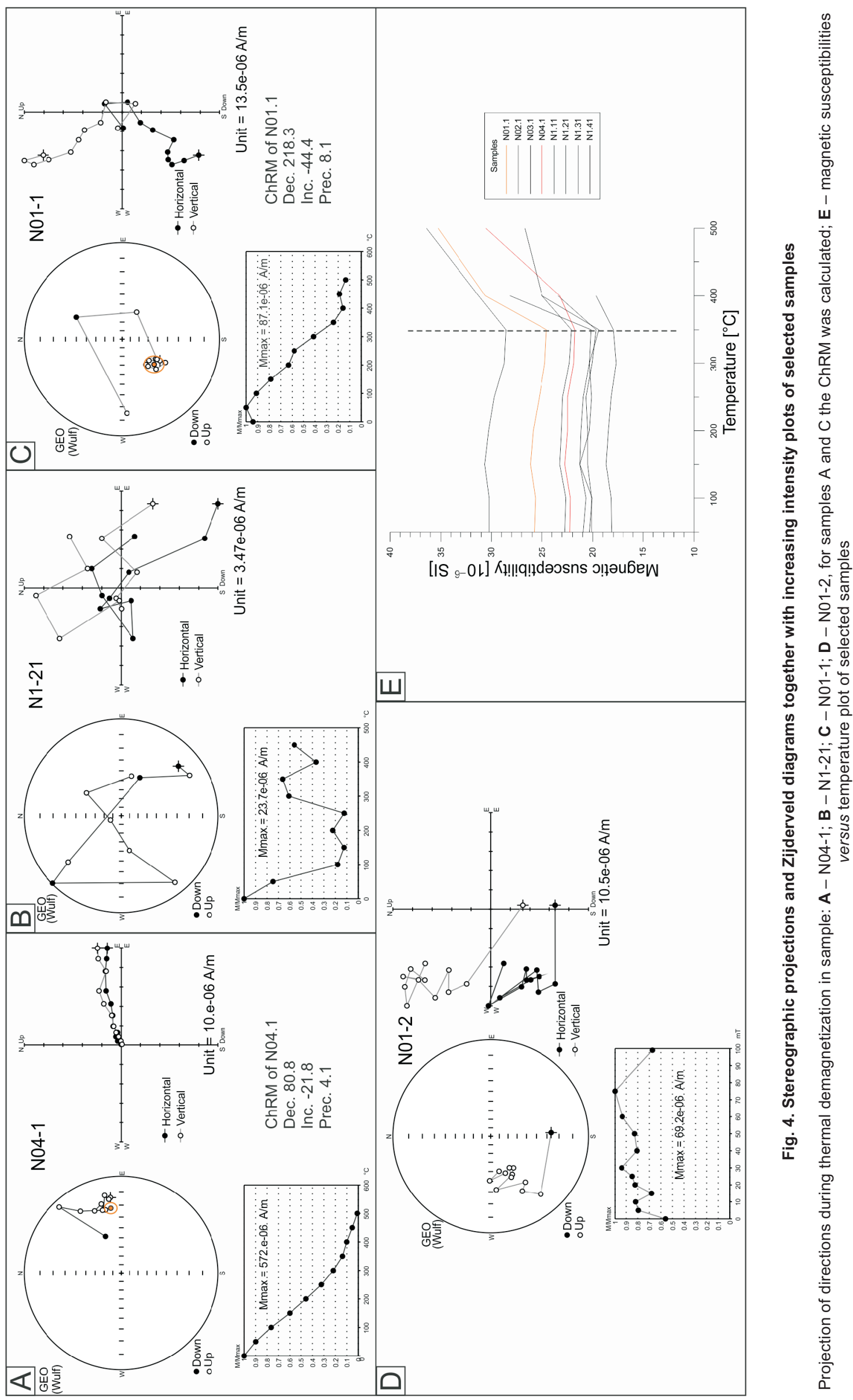


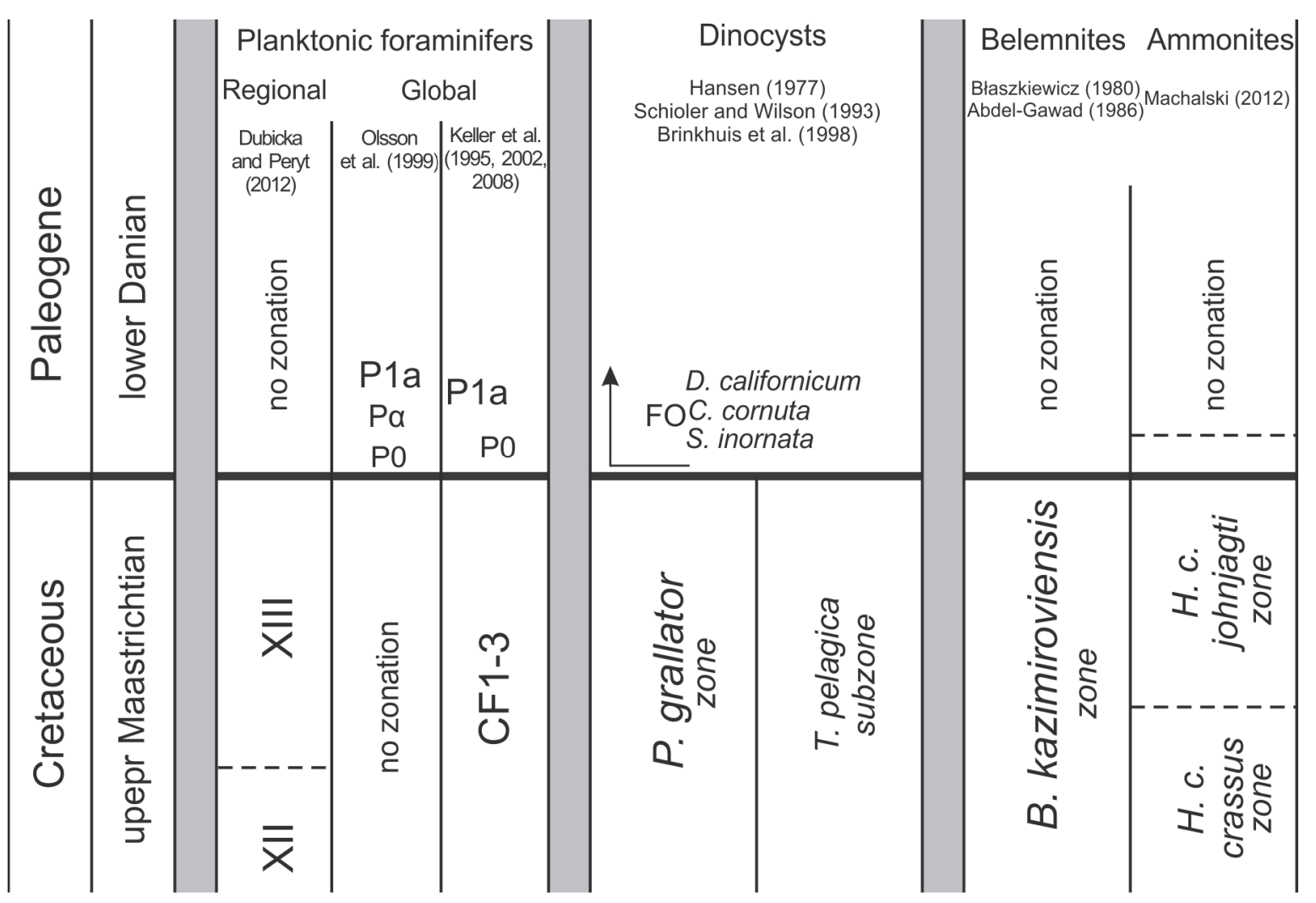

Fig. 5. Global and regional biostratigraphic subdivision of the upper Maastrichtian and lower Danian

Dinoflagellate cyst events defined as first or last occurrence of particular species (after Brinkhuis et al., 1998): $P$. Palynodinium, T. - Thalassiphora, S. - Senoniasphaera, C. - Carpatella, D. - Damassadinium, B. - Belemnella, H. c. Hoploscaphites constrictus

good preservation of organic walls. Selected species, out of over 60 taxa recognized, are illustrated in Figures 8 and 9 and all are listed in Table 1. The majority of the forms studied constitute a typical mid-latitude, boreal assemblage. The scarce occurrence of Danian dinoflagellate cyst species, i.e. of Carpatella cornuta and Senoniasphaera inornata in samples B4 and B4', coincides with an evident decreasing preservation ratio reflected by physical disintegration of specimens, suggesting reworking caused most likely by bioturbation.

HARDENED LIMESTONE - AN INCIPIENT HARDGROUND [UNIT II]

The hardened limestone representing an incipient hardground [unit II] yielded the following planktonic foraminifers: Archaeoglobigerina blowi Pessagno, Globigerinelloides multispinus (Lalicker), Gl. prairiehillensis Pessagno, Guembelitria cretacea Cushman, Muricohedbergella delrioensis (Carsey), M. planispira (Tappan), Planoheterohelix globulosa (Ehrenberg), P. navarroensis Loeblich, P. striata (Ehrenberg) and Rugoglobigerina pennyi Brönnimann. In general, the planktonic foraminiferal assemblage is dominated by biserial heterohelicids (abundance $>80 \%$ ) whereas Guembelitria forms comprise $\sim 10 \%$ of the assemblage. Such a composition indicates the regional Zone XII (sensu Dubicka and Peryt, 2012), which corresponds to the upper part of the Hoploscaphites constrictus crassus ammonite Zone (cf. Machalski, 2005b, 2012; Machalski et al., 2016; see Walaszczyk et al., 2016 for an overview; Figs. 5 and 9).

Stratigraphically important dinoflagellate cysts recorded in unit II, diagnostic for the upper Maastrichtian, are represented by Palynodinium grallator and Thalassiphora pelagica. $P$. grallator occurs commonly in samples B1-B4'; its last occurrence is recorded in sample B5', thus within the lower Danian, as defined here (= lowermost Siwak unit, above the phosphatic layer; Fig. 10), where it is extremely rare. In turn, T. pelagica, the latest Maastrichtian marker species, is encountered already in the lowermost sample studied B-1 [unit II] (Fig. 10), although it is very rare, as in other north European sections (compare Schiøler and Wilson, 1993; Schiøler et al., 1997).

MARLY CHALK [UNIT III]

The marly chalk [unit III] (samples x2 and x3; Fig. 10) yielded the following planktonic foraminiferal species: Archaeoglobigerina blowi Pessagno, A. cf. bosquensis Pessagno; Globigerinelloides multispinus (Lalicker), Gl. prairiehillensis Pessagno, Globotruncana arca (Cushman), Guembelitria cretacea Cushman, Muricohedbergella delrioensis (Carsey), M. planispira (Tappan), Planoheterohelix globulosa (Ehrenberg), P. navarroenis Loeblich, $P$. striata (Ehrenberg), Rugoglobigerina hexacamerata Brönnimann, R. milamensis Smith and Pessagno, and R. rugosa (Plummer) (Fig. 10). In general, the planktonic foraminiferal assemblage of unit III is dominated by biserial heterohelicids and triserial guembelitriids. Trochospiral taxa with globular chambers (Rugoglobigerina, Archaeoglobigerina) and keeled forms (Globotruncana) occur only sporadically and their abundance oscillates around a couple of percent. Benthic foraminifers from the marly chalk are represented by Bolivina incrassata (Reuss) (8\%), Cibicides ventratumidus Myatlyuk (3\%), Cibicidoides bembix (Marsson) 


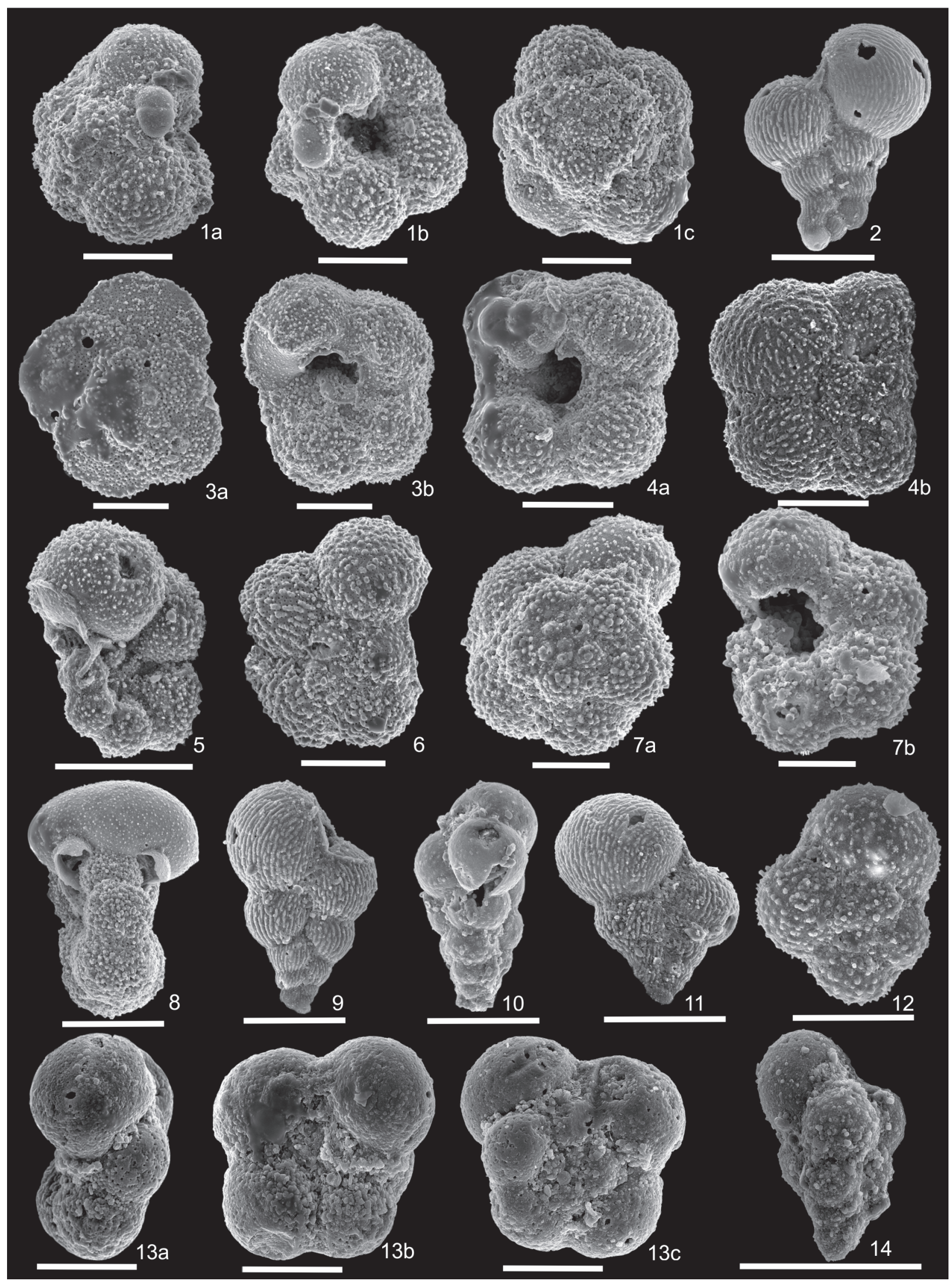

Fig. 6. SEM images of planktonic foraminifers from the marly chalk [unit III] and the GQSU

1a-c - Rugoglobigerina milamensis Smith and Pessagno, sample x2; 2 - Planoheterohelix globulosa (Ehrenberg), sample x2; 3a, b Globotruncana arca (Cushman), sample x2; 4a, b-Rugoglobigerina rugosa (Plummer), sample x2; 5 - Globigerinelloides prairiehillensis Pessagno, sample x2; 6 - Rugoglobigerina hexacamerata Brönnimann, sample x2; 7a, b - Archaeoglobigerina cf. bosquensis Pessagno, sample x2; 8 - Globigerinelloides multispinus (Lalicker), sample x2; 9 - Planoheterohelix striata (Ehrenberg), sample x2; 10 - Guembelitria cretacea Cushman, sample x2; 11 - Planoheterohelix globulosa (Ehrenberg), sample ×2; 12 - Muricohedbergella delrioensis (Carsey), sample x2; 13a-c-Muricohedbergella holmdelensis (Olsson), sample x4; 14 - Guembelitria cretacea Cushman, sample x4; scale bars - 100 m 


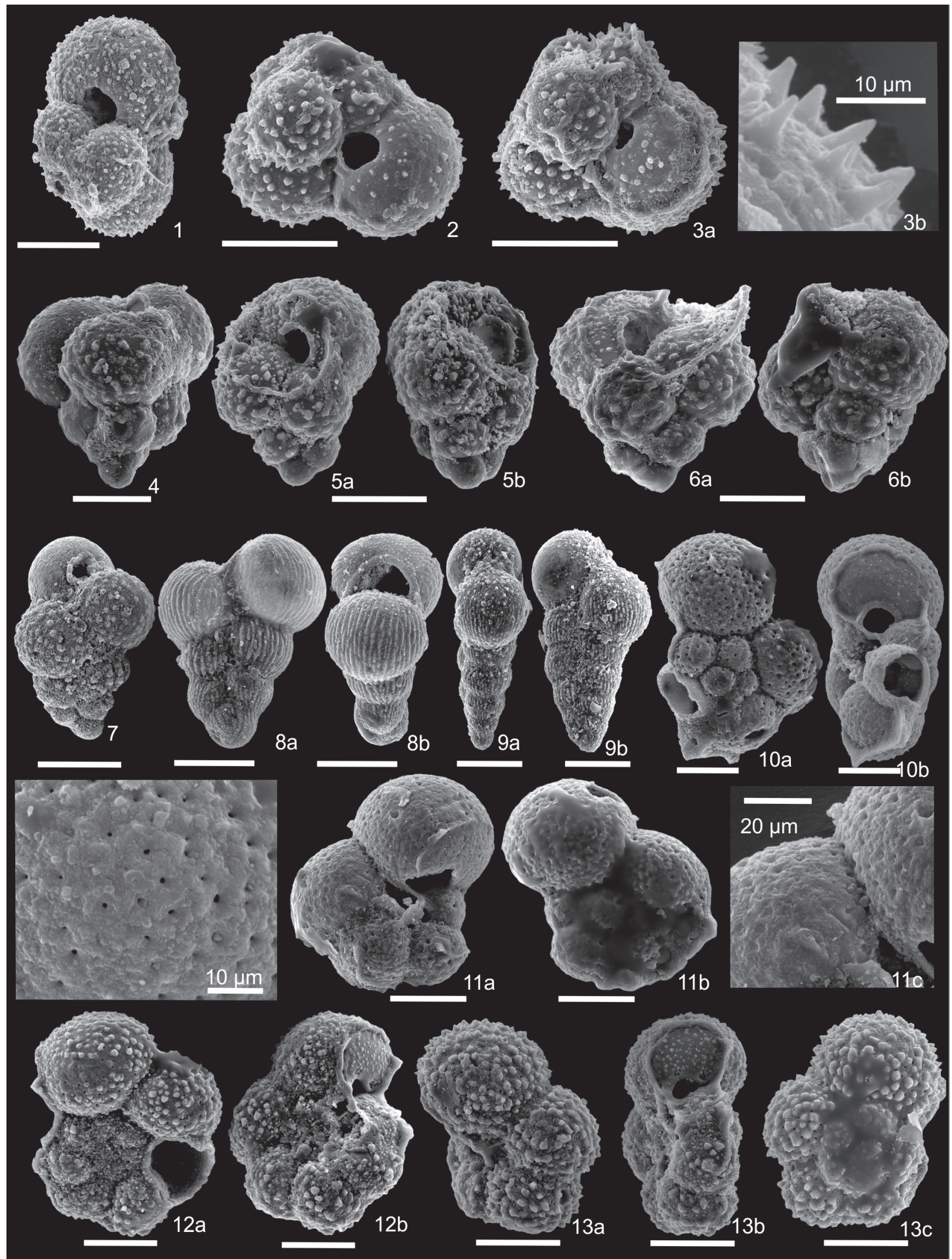

Fig. 7. SEM images of planktonic foraminifers from the basal Siwak unit at Nasiłów

1 - Globoconusa daubjergensis (Brönnimann), sample x5; 2 - Globoconusa daubjergensis (Brönnimann), sample x8; 3a, b - Globoconusa daubjergensis (Brönnimann), sample x8; 4 - Parvularugoglobigerina alabamensis (Liu and Olsson), sample x5; 5a, b - Parvularugoglobigerina alabamensis (Liu and Olsson), sample x4; 6a, b-Parvularugoglobigerina alabamensis (Liu and Olsson), sample x8; 7 Parvularugoglobigerina extensa (Blow), sample x5; 8a, b - Planoheterohelix globulosa (Ehrenberg), sample x5; 9a, b - Planoheterohelix navarroensis Loeblich sample x8; 10a-c - Muricohedbergella monmouthensis (Olsson), sample x8; 11a-c - Muricohedbergella monmouthensis (Olsson), sample $\mathrm{x} 8$; 12a, $\mathrm{b}$ - Muricohedbergella planispira (Tappan), sample $\mathrm{x} 8 ; 13 \mathrm{a}, \mathrm{b}-$ Muricohedbergella delrioeinsis (Carsey), sample x8; scale bars $-50 \mu \mathrm{m}$ 


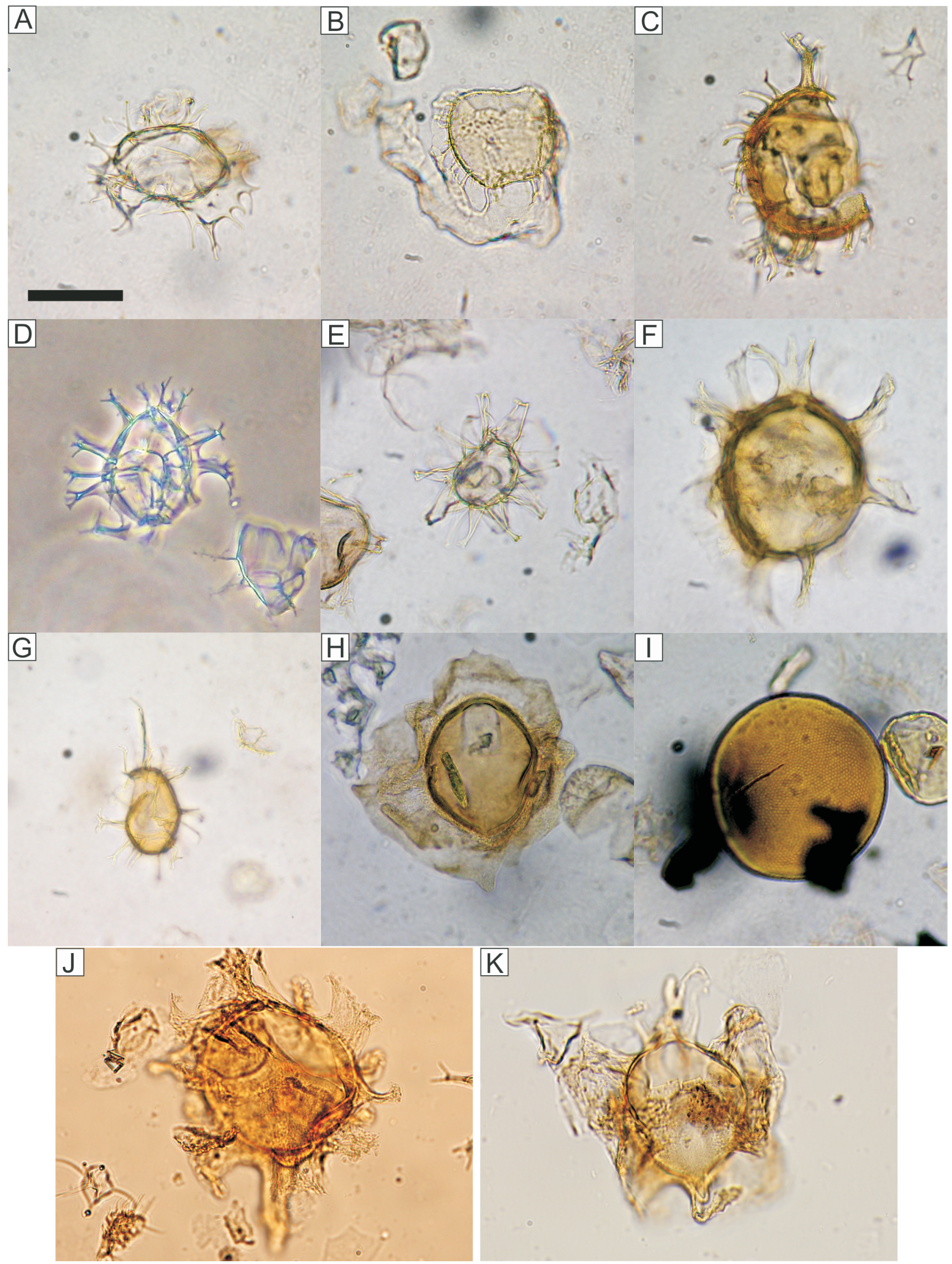

Fig. 8. Selected upper Maastrichtian and lower Danian dinoflagellate cysts from the KTB interval at Nasiłów

A - Palynodinium grallator Gocht, 1970, sample B4; B - Glaphyrocysta perforata Hultberg and Malmgren, 1985, sample B6; C - Fibrocysta axialis (Eisenack, 1965) Stover and Evitt, 1978, sample B2; D - Spiniferites ramosus (Ehrenberg, 1838), sample B4'; E Kleithriasphaeridium truncatum (Benson, 1976), sample B1; F - Cordosphaeridium exilimurum Davey and Williams 1966, sample B5; G Spiniferites cornutus (Gerlach, 1961), sample B1; H - Thalassiphora pelagica (Eisenack, 1954), sample B1; I - Tasmanites sp., sample B2; J - Disphaerogena carposphaeropsis, sample B3; K - Damassadinium californicum, sample B7; scale bar - $30 \mu \mathrm{m}$ 


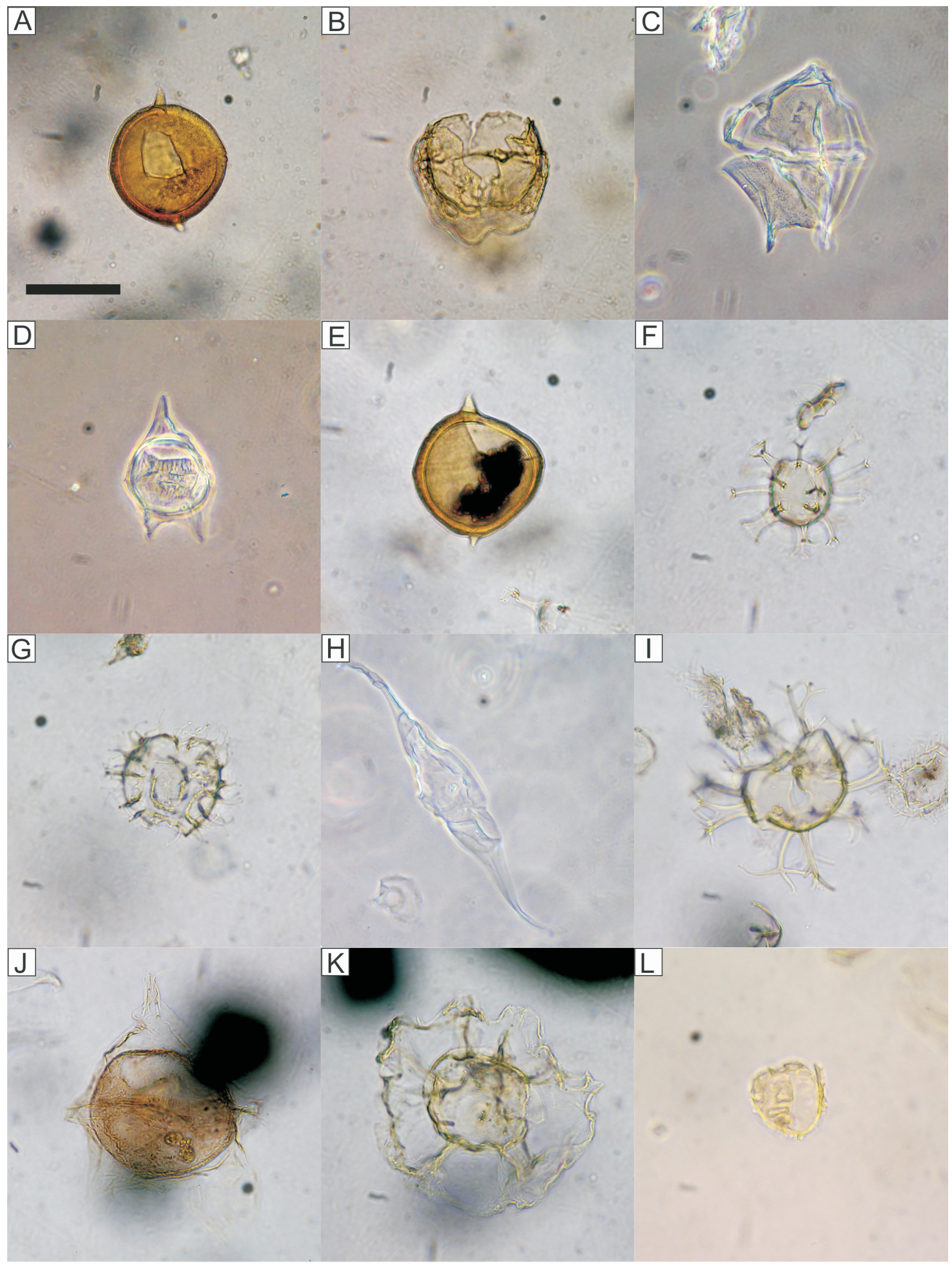

Fig. 9. Selected upper Maastrichtian and lower Danian dinoflagellate cysts from the KTB interval at Nasiłów

A - Carpatella cornuta Grigorovich, 1969, sample B5; B - Senoniasphaera inornata (Drugg, 1970), sample B5; C - Palaeoperidinium pyrophorum (Ehrenberg, 1838 ex Wetzel, 1933), sample B4; D - Deflandrea galeata (Lejeune-Carpentier, 1942), sample B5; E - Carpatella cornuta Grigorovich, 1969, sample B4'; F - Hystrichosphaeridium tubiferum (Ehrenberg, 1838), sample B2; G - Areoligera senonensis Lejeune-Carpentier, 1938, sample B1; H - Palaeocystodinium golzowense Alberti, 1961, sample B5'; I - Achomosphaera ramulifera (Deflandre, 1937), sample B3; J - Cerodinium speciosum (Alberti, 1959), sample B3; K - Rigaudella apenninica (Corradini, 1973), sample B4; L - Eisenackia circumtabulata Drugg, 1967, sample B7; scale bar - $30 \mu \mathrm{m}$ 


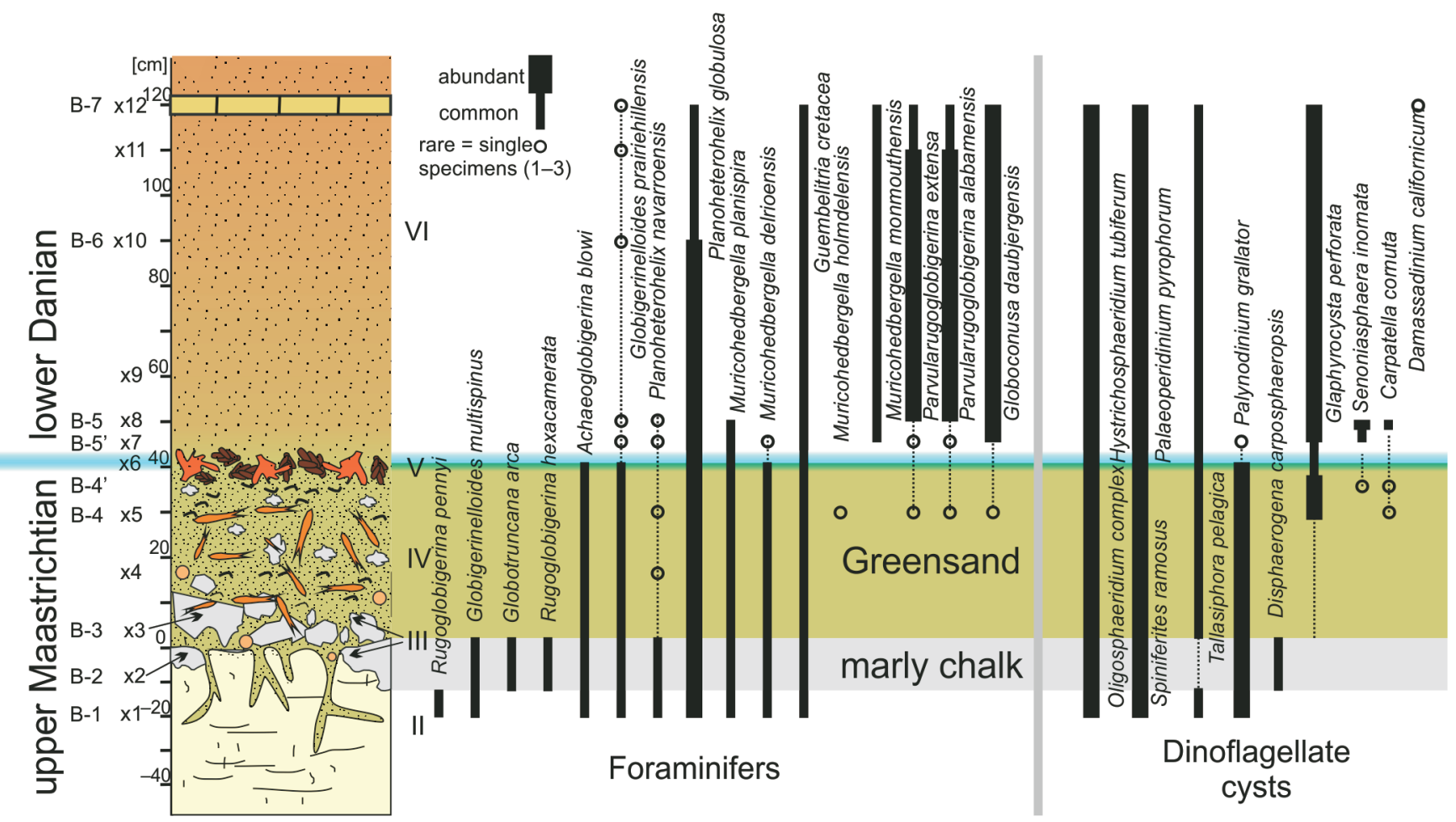

Fig. 10. Ranges of selected planktonic foraminifers and dinoflagellate cysts

The K-Pg boundary is marked by the blue line

(10\%), C. succedens (Brotzen) (7\%), Gavelinella sahlstroemi (Brotzen) $(18 \%)$, Osangularia sp. (5\%), Praebulimina parvula (Brotzen) (12\%), Pyramidina sp. (13\%); the other taxa composed $\sim 20 \%$.

Within this unit, the dinoflagellate cysts assemblage is similar to that recognized in the underlying hardened limestone [unit II] (Fig. 10). Only the presence of Disphaerogena carposphaeropsis constitutes an important difference.

\section{GREENSAND [UNIT IV] AND THE PHOSPHATIC LAYER [UNIT V]}

The Greensand [unit IV] displayed exclusively Upper Cretaceous planktonic foraminifers such as Archaeoglobigerina blowi Pessagno, Globigerinelloides prairiehillensis Pessagno, and Cretaceous-Paleogene transitional forms - the so-called disaster opportunist species such as Guembelitria cretacea ( $7 \%$ of the assemblage), Muricohedbergella planispira (Tappan) $(\sim 6 \%)$ and heterohelicids i.e. Planoheterohelix. navarroensis ( 2\%) and $P$. globulosa ( 72\%) (Fig. 10). Thus the Greensand is dominated by mostly the same planktonic foraminifers as recognized in the two underlying units, i.e. the hardened limestone [unit II] and the marly chalk [unit III], however, they are less frequent and exhibit a worse state of preservation. Interestingly, the upper part of the Greensand (sample x5; Fig. 10) yielded additionally one or two specimens of lowermost Danian species: Parvularuglobigerina alabamensis (Liu and Olsson), Parvularuglobigerina extensa (Blow), and Globoconusa daubjergensis (Brönnimann).

The dinoflagellate cyst assemblage from the Greensand is generally similar to that recognized in the two underlying lithological units (II and III; Fig. 10), with the exception of the first and massive appearance of Glaphyrocyata perforata (cf. Table 1). As in the case of the foraminifers, single specimens of typically Danian dinoflagellate cysts, Carpatella cornuta and Senoniasphaera inornata, were also found in samples B-4 and/or B-4' (Fig. 10), thus directly within the limits of the phosphatic layer [unit V] or just below (Fig. 10).

$$
\text { SIWAK [UNIT VI] }
$$

The massive appearance of the lower Danian foraminifers starts just above the phosphatic layer (sample x7; Fig. 3) with absolute domination by Globoconusa daubjergensis ( $45 \%$ of the assemblage). Higher in the section (samples $x 8-x 12)$ this species constitutes up to $70 \%$ of the assemblage. Species of the genus Parvularugoglobigerina ( $P$. extensa and $P$. alabamensis) constituate up to $26 \%$. They are accompanied by co-occurring upper Maastrichtian survivors i.e. G. cretacea ( $\sim 8$ to $2 \%$ decreasing upwards), Muricohedbergella monmouthensis (Olsson) (11\% to $5 \%$ decreasing upwards), Planoheterohelix. globulosa (Ehrenberg) (22 to 10\% decreasing upwards). Other species, such as M. planispira (Tappan) and $P$. navarroensis (Loeblich), are less common.

The most indicative dinoflagellate cyst marker species for the lower Danian are Carpatella cornuta, Senoniasphaera inornata, and Damassadinium californicum. The first species constitutes $\sim 5 \%$, the second species $\sim 10 \%$ of the assemblage in sample B-5, just above the phosphatic layer [unit V], thus within the lowermost part of the Siwak unit (Fig. 10); $D$. californicum has its FO in sample B7, $80 \mathrm{~cm}$ above the K-Pg boundary as defined here and it is very rare (Fig. 10). 
Table 1

Frequency of dinoflagellate cysts in the samples studied; counts up to 300 specimens per sample

\begin{tabular}{|c|c|c|c|c|c|c|c|c|c|c|}
\hline & Sample & B1 & B2 & B3 & B4 & B4' & B5' & B5 & B6 & B7 \\
\hline 1 & Achomosphaera ramulifera & 13 & & 14 & & 12 & & & & \\
\hline 2 & Achomosphaera sagena & 9 & 19 & 5 & & 6 & & & & 9 \\
\hline 3 & Alterbidinium acutulum & & 2 & & 1 & & & & & \\
\hline 4 & Areoligera coronata & 19 & & & & 18 & 23 & 15 & & 21 \\
\hline 5 & Areoligera senonensis & 17 & & & & 15 & 20 & 12 & & \\
\hline 6 & Areoligera spp. & & & & & & & & & \\
\hline 7 & Batiacasphaera spp. & 8 & 11 & & & & & & & \\
\hline 8 & Caligodinium spp. & & & & & & & & 2 & 1 \\
\hline 9 & Carpatella cornuta & & & & 1 & 1 & & 16 & & \\
\hline 10 & Cerodinium spp. & 2 & & 12 & & 8 & & & & \\
\hline 11 & Cerodinium speciosum & 16 & & 21 & 17 & & 21 & & 17 & \\
\hline 12 & Cerodinium wardenense & & & & & & & & 2 & \\
\hline 13 & Cleistosphaeridium spp. & & & & & & & & 12 & 3 \\
\hline 14 & Cordosphaeridium exilimurum & & & & & & & 7 & & \\
\hline 15 & Cordosphaeridium fibrospinosum & 7 & 6 & 6 & & 14 & & 5 & & 4 \\
\hline 16 & Cordosphaeridium inodes & 6 & 4 & 5 & & 11 & & 8 & & \\
\hline 17 & Cordosphaeridium spp. & & & & & & & 2 & & 4 \\
\hline 18 & Cribroperidinium ventriosum & & & & 1 & 3 & & & & \\
\hline 19 & Cribroperidinium wetzelii & & 2 & 1 & & & & & & \\
\hline 20 & Damassadinium californicum & & & & & & & & & 2 \\
\hline 21 & Deflandrea galeata & & & & & & 1 & 4 & & 3 \\
\hline 22 & Disphaerogena carposphaeropsis & & 6 & 3 & & & & & & \\
\hline 23 & Eisenackia circumtabulata & 5 & 8 & & & 6 & & 9 & 5 & 4 \\
\hline 24 & Exochosphaeridium bifidum & & & & & & 4 & & 5 & \\
\hline 25 & Exochosphaeridium truncigerum & 1 & & 2 & 1 & & & & & \\
\hline 26 & Fibrocysta axialis & 12 & 18 & & 5 & 9 & 22 & 17 & 6 & 9 \\
\hline 27 & Glaphyrocysta perforata & & & & 23 & 17 & 9 & 19 & 27 & 28 \\
\hline 28 & Glaphyrocysta semitecta & 6 & & 8 & 10 & 11 & 5 & & 6 & 12 \\
\hline 29 & Heterosphaeridium spp & 9 & 11 & 3 & 22 & 12 & 2 & 3 & 5 & 3 \\
\hline 30 & Hystrichosphaeridium salpingophorum & 1 & 2 & & & & & & & \\
\hline 31 & Hystrichosphaeridium recurvatum & & 6 & 15 & & & 12 & & 11 & \\
\hline 32 & Hystrichosphaeridium tubiferum & 33 & 36 & 29 & 48 & 21 & 26 & 41 & 61 & 49 \\
\hline 33 & Hystrichostrogylon spp. & & & & & 2 & 4 & & & \\
\hline 34 & Isabellidinium cooksoniae & & & & & 1 & & & & \\
\hline 35 & Kleithriasphaeridium truncatum & 1 & & & 2 & & & & & \\
\hline 36 & Kleithriasphaeridium loffrense & 2 & & & & 2 & & & & \\
\hline 37 & Lanternosphaeridium reinhardtii & & & & & & & 2 & & 2 \\
\hline 38 & Minisphaeridium spp. & & & & & & & & & 3 \\
\hline 39 & Oligosphaeridium complex & 47 & 54 & 62 & 55 & 29 & 41 & 32 & 65 & 59 \\
\hline 40 & Operculodinium centrocarpum & & & 1 & & & & & 6 & 3 \\
\hline 41 & Palaechystrichophora infusoroides & 2 & & & & & & & & \\
\hline 42 & Palaeoperidinium pyrophorum & 8 & 6 & 12 & 35 & 18 & 15 & 24 & & 12 \\
\hline 43 & Paleocystodinium golzowense & & & & 15 & & 13 & & 18 & 7 \\
\hline 44 & Palynodinium grallator & 19 & 27 & 26 & 16 & 14 & 2 & & & \\
\hline 45 & Pervosphaeridium multispinum & 5 & 6 & 2 & & 7 & 8 & 7 & 4 & \\
\hline 46 & Phelodinium magnificum & & & 1 & & 3 & & & & \\
\hline 47 & Riculacysta pala & & 3 & 9 & 11 & & & & & \\
\hline 48 & Rigaudella apenninica & 11 & 15 & 17 & 8 & 11 & & & 20 & 6 \\
\hline 49 & Samlandia sp. & 1 & 2 & & & & & & & \\
\hline
\end{tabular}


Tab. 1 cont.

\begin{tabular}{|l|c|c|c|c|c|c|c|c|c|c|}
\hline 50 & Senegalinium spp. & & & 1 & 2 & & & & & \\
\hline 51 & Senoniasphaera inornata & & & & & 2 & 6 & 21 & & \\
\hline 52 & Spiniferites cornutus & 2 & & 5 & 3 & & & & 7 & \\
\hline 53 & Spiniferites ramosus grp. & 23 & 48 & 35 & & 30 & 48 & 39 & & 42 \\
\hline 54 & Surculosphaeridium spp. & 2 & & 5 & 18 & 3 & 7 & & & \\
\hline 55 & Tanyosphaeridium regulare & & 1 & & 3 & & 2 & & & \\
\hline 56 & Tanyosphaeridium spp. & & & & & 5 & & 9 & & \\
\hline 57 & Tanyosphaeridium xanthiopyxides & 3 & 7 & & & & & & & \\
\hline 58 & Tectatodinium rugulatum & & & & & & & 1 & 3 & \\
\hline 59 & Thalassiphora pelagica & 7 & & & 2 & 9 & 6 & 7 & 11 & 14 \\
\hline 60 & Tricodinium castanea & & & & & & & & 2 & \\
\hline 61 & Trithyrodinium evitti & & & & 1 & & 3 & & 3 & \\
\hline 62 & Xenascus ceratoides & 3 & & & & & & & & \\
\hline 63 & Hafniasphaera cryptovesiculata & & & & & & & & 2 & \\
\hline
\end{tabular}

\section{INTERPRETATION AND DISCUSSION}

\section{MAGNETOSTRATIGRAPHY}

The first and the only palaeomagnetic data from the Nasiłów section were provided by Hansen et al. (1989). He argued for remagnetization from the $30 \mathrm{~N}$ to $29 \mathrm{R}$ palaeomagnetic interval just above the phosphatic layer. However, the procedures and reliability of the magnetostratigraphic measurements executed by Hansen et al. (1989) can be questioned. They applied only alternating field demagnetization techniques and results as a basis for interpretation were obtained only from the $10 \mathrm{mT}$ level of demagnetization, which brings another question, whether the directions obtained are stable and primary? Unfortunately, petromagnetic results as well as declinations, statistic data such as the $\alpha 95$ semi-angle at $95 \%$ confidence level, and $\mathrm{K}-$ precision parameter were not provided.

Our studies showed that alternating field techniques failed in the samples analysed, and during thermal heating the thermomagnetic changes destroyed the primary magnetization. We consider that magnetostratigraphy cannot be treated as a reliable stratigraphic tool for the Nasiłów section, mostly due to the very weak magnetization of the samples analysed and the large abundance of goethite. The latter cannot serve as an important magnetic carrier, but as an unstable antiferromagnet; it frequently destroys the palaeomagnetic record during heating procedures (e.g., Gubbins and Herrero-Bervera, 2007, and references therein).

Summarizing, these questions undermine the reliability of stable, primary directions obtained by Hansen et al. (1989) and accordingly, undermine their palaeomagnetic results. Our palaeo- and petromagnetic investigations showed that no stable primary or secondary magnetic direction can be identified in the samples analysed (even in specimens cut from the same sample). Consequently, the duration of the hiatus, supposing to encompass the latest Maastrichtian and earliest Danian, as interpreted from magnetostratigraphic data, cannot be demonstrated in the light of new data.

\section{BIOSTRATIGRAPHY}

HARDENED LIMESTONE - AN INCIPIENT HARDGROUND [UNIT I]

The presence of the zonal index dinoflagellate cyst species $T$. pelagica indicates that at least the upper $20 \mathrm{~cm}$ of hardened limestone can be attributed to the uppermost Maastrichtian $T$. pelagica Subzone of the $P$. grallator Zone of Hansen (1977) (Figs. 5 and 9). Such a stratigraphic position is also shown by the acme of $P$. grallator in samples B1-B4' (Fig. 10), which is characteristic of the topmost Maastrichtian in the Boreal Realm and corresponds to the T. pelagica Subzone (e.g., Schiøler and Wilson, 1993). Other species such as Hystrichosphaeridium tubiferum, Oligosphaeridium complex, and Spiniferites ramosus occur abundantly in all samples studied (B1-B7; Table 1).

The first dinoflagellate cyst data from the Nasiłów section were provided by Hansen et al. (1989). He did not report the very last Maastrichtian biozonal species, T. pelagica, and hence, up to now, the hardened limestone has been considered to be upper, albeit not the uppermost Maastrichtian (e.g., Hansen et al., 1989; Machalski, 1998). Consequently, it was suggested that the highest levels of the Maastrichtian are missing in central Poland. In the light of the new dinoflagellate cyst data this point of view cannot be upheld.

Besides the age-diagnostic species of foraminifera (Dubicka and Peryt, 2012) and dinoflagellate cysts, the hardened limestone yielded the late Maastrichtian belemnites of the Belemnella kazimiroviensis group (e.g., Keutgen et al., 2017), as well as ammonites, i.e. frequent Hoploscaphites constrictus crassus (Łopuski), rare Menuites terminus (Ward and Kennedy) and Sphenodiscus binckhorsti (Böhm) (Machalski, 1998, 2005a, b).

\section{MARLY CHALK [UNIT III]}

The composition of the foraminiferal assemblage from the marly chalk, especially the bloom of guembelitriids (e.g., Abramovich et al., 1998; Pardo and Keller, 2008; Dubicka and Peryt, 2012; Machalski et al., 2016) indicated an uppermost Maastrichtian position for the marly chalk, of regional assemblage Zone XIII (Dubicka and Peryt, 2012), which covers the uppermost part of the H. c. crassus and the entire H. c. johnjagti ammonite zones (Figs. 5 and 9; also Machalski et al., 2016). Moreover, the planktonic and benthic foraminiferal taxa recorded in this unit are characterized by a reduction in specimen size (dwarfism). Intraspecies size reductions (Lilliput effect) of planktonic (Keller and Abramovich, 2009; Tantawy et al., 2009; Punekar et al., 2014a, b) and benthic foraminifers (Machalski et al., 2016) are typically observed near the end of the Cretaceous and interpreted as a response to the Deccan volcanism (possibly the 2 nd most extensive phase), causing climate changes 


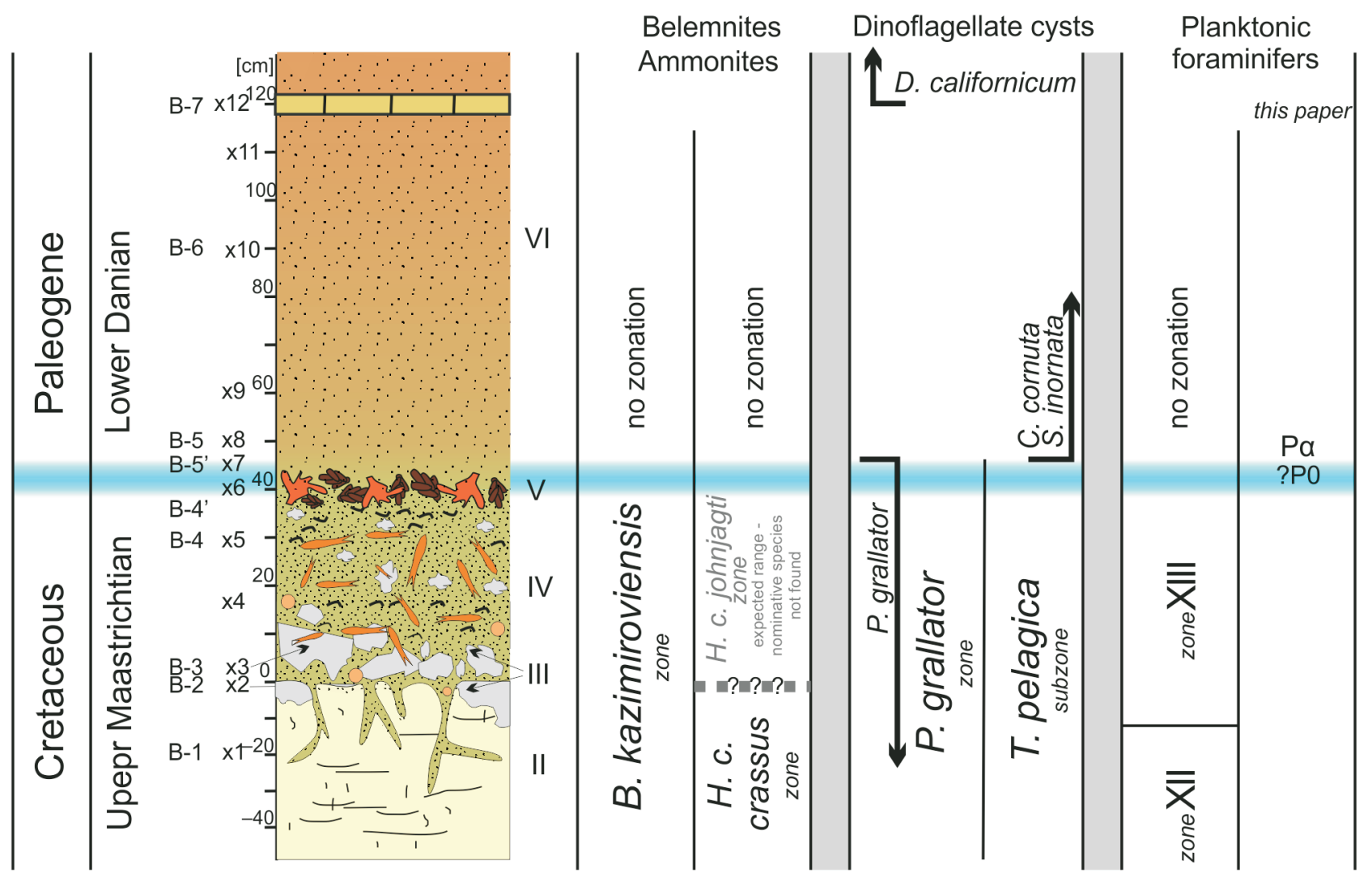

Fig. 11. Biostratigraphic subdivision of the Nasiłów section

For regional and global zonation see Figure 5; the K-Pg boundary at the top of the phosphatic layer is marked by the blue line; arrows indicate first (arrow up) and last (arrow down) occurrences of selected dinoflagellate cyst species

and ocean acidification (e.g., Punekar et al., 2014a, b; Schoene et al., 2015). Such high-stress environmental assemblages of foraminifers were recently described by Machalski et al. (2016) from the Lechówka section near Chełm, SE Poland $(\sim 100 \mathrm{~km}$ from Nasiłów). These small (frequently less than one-third of their normal adult size) forms occur in the Lechówka section in the lower part of the local marly unit $D$, which is placed entirely in the uppermost Maastrichtian, just below the boundary clay (Machalski et al., 2016). Surprisingly, the benthic foraminiferal assemblage from the $\sim 30(?) \mathrm{cm}$ thick marly unit $D$ of the Lechówka section (cf. Machalski et al., 2016) is very similar to that from the marly chalk [unit III] currently recognized at Nasiłów. Accordingly, both marly units at Nasiłów [unit III] and Lechówka (unit D) seem to correspond to each other, representing equivalents of the terminal Maastrichtian deposits, which can be attributed either to the uppermost part of the $H$. $c$. crassus or most likely to the $H$. c. johnjagti ammonite Zone (Fig. 11).

The marly chalk yielded a similar dinoflagellate cyst composition as did the underlying hardened limestone [unit II] (Fig. 10). The important difference is the presence of the typically latest Maastrichtian Disphaerogena carposphaeropsis. This species has its first occurrence in the latest Maastrichtian (e.g., Benson, 1976; Brinkhuis and Zachariasse, 1988) and together with $P$. grallator and $T$. pelagica can serve as a good proxy for the terminal Maastrichtian age of the marly chalk (Figs. 8 and 9). Additionally, this unit has yielded belemnites of the Belemnella kazimiroviensis group recently analysed by Keutgen et al. (2017).
The white-grey marly chalk [unit III] overlies an uneven surface of the hardened limestone [unit II] (Fig. 3) and occurs also in clasts dispersed within the overlying Greensand (Fig. 3). Clasts of such lithology, together with the infillings of belemnite alveoli and brachiopod shells, comprise a well-known component of the Greensand and have been previously recorded by several authors (e.g., Pożaryska, 1965; Machalski and Walaszczyk, 1987; Hansen et al., 1989; Żarski et al., 1998; Machalski, 1998, amongst other). The brecciated character of the white-grey marly chalk, especially in the lower portion of the Greensand, has been interpreted as a strongly brecciated cover of the incipient hardground formed during burrowing that was taking place already in early or even middle Danian times (Fig. 3; "pseudo-breccia" of Machalski, 1998). Consequently, this marly-chalk-like lithology, although definitely younger, was considered as an approximate time-equivalent of the hardened limestone, and possibly for that reason never subjected to a separate biostratigraphic examination of widely accepted, stratigraphically important taxa.

GREENSAND [UNIT IV] AND THE PHOSPHATIC LAYER [UNIT V]

The domination of almost exclusively upper Maastrichtian foraminifers in the Greensand, similar to that recognized in the underlying marly chalk and incipient hardground, indicates the uppermost Maastrichtian position of the Greensand and the regional assemblage Zone XIII (Dubicka and Peryt, 2012).

The same terminal Maastrichtian age of the Greensand can be worked out based on the dinoflagellate assemblage. Since the Greensand clearly originates from reworking of older depos- 
its (the presence of chalk-like shards floating in the Greensand and the presence of fauna of different ages and provenance), the common occurrence of $G$. perforata ( $8 \%$ of the assemblage), which first appears in the uppermost Maastrichtian (e.g., Brinkhuis and Zachariasse, 1988), and its lack in the underlying marly chalk (Fig. 10 and Table 1), implies that deposits slightly younger then the marly chalk were previously also present at or outside the Nasiłów area. Those deposits were subsequently washed out and redeposited as the Greensand, forming a terminal Maastrichtian dinoflagellate cyst assemblage rich in $G$. perforata.

Interestingly, the upper portion of the Greensand yielded a very few specimens of typically Danian foraminifers and dinoflagellate cysts. This, at first glance, would suggest a Danian age for the upper portion of the Greensand; however, because this unit is bioturbated at least to some degree, those few individuals might have been secondarily introduced into the Greensand, translocated downwards by burrowers during bioturbation, or represent simple contamination during the sampling procedure, which cannot be excluded. This is supported by a worse state of preservation of foraminiferal tests and dinoflagellate cysts, which might suggest reworking. Additionally, such mixing of foraminifers during bioturbation is a common phenomenon and should be expected, rather than the lack of such an effect.

Since the age of the Greensand is critical for the overall understanding of the K-Pg section at Nasiłów, the presence of supposed Paleocene macro- and microfaunal assemblages suggesting its Danian age requires additional comment. Especially so, given that the terminal Maastrichtian age of the Greensand, as based on new foraminifers and dinoflagellate cyst results, contradicts the opinion of its Danian age favoured previously by several authors (e.g., Pożaryska, 1965; Krach, 1981; Hansen et al., 1989; Żarski et al., 1998; Machalski, 1998, 2005a, b, 2012; Świerczewska-Gładysz and OlszewskaNejbert, 2006; Racki et al., 2011; Machalski et al., 2016; Machalski and Jagt, 2018).

Pożaryska (1965) assumed the Danian age of the Greensand based on its correlation with the subsurface "Sochaczew Beds", suggesting that the "Żyrzyn Beds" of latest Maastrichtian age are absent from the Nasiłów section. However, the samples studied directly from the surface exposures at Nasiłów or Bochotnica lack precise locations within the section, and therefore the exact provenance of the foraminifers studied remains unclear.

Krach (1981) suggested that the whole Greensand and overlying Siwak should be interpreted as one depositional cycle (Krach, 1981) of Paleocene (Montian) age. However, Krach (1981) neither defined precisely how he understood his glauconitic sandstone nor the overlying Siwak. On the other hand, Krach (1981) emphasized that the lower portion of his glauconitic sandstone is characterized by an allochthonous Upper Cretaceous faunal assemblage which is followed upwards by a Paleocene one.

By contrast, Radwański (1985, 1996), Abdel-Gawad (1986), and Machalski and Walaszczyk (1987) for different reasons and based on different sedimentological concepts, argued for the Maastrichtian age of the Greensand. Radwański (1985) placed the boundary at the top of the phosphatic layer based on the stratigraphic distribution of scaphidids and belemnitelids, as did Abdel-Gawad (1986). Machalski and Walaszczyk (1987) reported a Danian macrofauna from the Greensand, although only from the phosphatic layer, immediately below this level or above, forming patchy occurrences. Those were interpreted to show their secondary introduction into the Greensand by infaunal activity. The only exceptions were burrowing bivalves considered as Danian of the genera Nucula and Cucullaea, which most likely penetrated slightly deeper into the Greensand. Although those authors placed the K-Pg boundary within the Greensand, particularly at the base of the phosphatic layer, the suggested Maastrichtian age of the Greensand is consistent with our new biostratigraphic data presented herein.

Żarski et al. (1998) considered the Greensand to be Danian in age, based mainly on the foraminifera. However, the lowest occurrence of the typical Danian form reported by him, i.e. Globoconusa daubjergensis, has been recorded from just above or within the main phosphatic layer. Hence, the data of Żarski et al. (1998) demonstrate only the Danian age of the Siwak, thus the unit starting from the phosphatic layer upwards.

Machalski and Jagt (2018), based on echinoid assemblages from the Greensand, sustained the concept of its Danian age, considering it as a condensed, transgressive unit with mixed faunas of different age and provenance. The recognized echinoid assemblages were dated from the late Maastrichtian to late Danian, however, no definitions for the lower, middle and upper Danian were provided. Since most of the phosphatized echinoids were found ex-situ, their exact provenance within the boundary interval is unknown - in fact those loose specimens might come both from the Greensand or overlying Siwak. In addition, the "probably younger" assemblage (i.e. upper Danian) consists of two forms (four specimens) that were only tentatively assigned to a species level, being characterized by a kind of "ghost preservation" with few or no details available. Similarly, as in the case of the phosphatized assemblage, in the "probably younger" assemblage only one specimen holds a precise location within the section, which is not the Greensand, but the lower portion of the Siwak (0.2 $\mathrm{m}$ above the phosphatic layer; cf. Machalski and Jagt, 2018). Our new biostratigraphic data indicate that this specimen is of lower Danian age - not as advocated by Machalski and Jagt (2018) being of middle or even upper Danian. Summarizing, in the light of the lack of precise locations for most of the echinoids analysed and the uncertain age of the "probably younger" echinoid assemblage (middle to upper Danian), this material cannot pretend to be age-diagnostic for the Greensand - the most important unit within the boundary interval.

Additionally, taking into account all the new biostratigraphic data and redeposited character of the macrofauna within the Greensand, the question, whether all the forms considered Paleocene in age are really of that age, is reasonable and should be asked. We have to bear in mind that we know little or nothing about the faunal composition of the highest levels of the Maastrichtian succession, formerly present and currently eroded, supplying the Greensand with macrofaunal assemblages unknown from the underlying Kazimierz Opoka. It may be speculated that at least part of the supposed Paleocene macrofauna, having, in fact, no independent age control, may simply come from the eroded part of the terminal Maastrichtian sequence.

Summarizing, the former explanation of the above contradictory age-data of the Greensand, i.e. the secondary introduction of some supposed Danian fossils by infaunal activity, proposed by Machalski and Walaszczyk (1987) was subsequently rejected by Hansen et al. (1989) and Machalski (1998), and followed by all subsequent authors who assumed a Danian age of the Greensand (e.g., Hansen et al., 1989; Żarski et al., 1998; Machalski, 1998, 2005a, b, 2012; Świerczewska-Gładysz and Olszewska-Nejbert, 2006; Racki et al., 2011; Machalski et al., 2016; Machalski and Jagt, 2018). The inference of a Danian age of the Greensand brings, however, several problems and in our opinion has the following drawbacks, listed below. 
How can one explain the almost complete absence of diagnostic Danian foraminifers and dinoflagellate cysts and a domination by upper Maastrichtian and transitional Maastrichtian/Danian forms in the Greensand, if one assumes its Danian age? Their composition within the Greensand would rather be expected to be opposite, as is the case just above the phosphatic layer where Danian forms are abundant and diverse. Why is the supposed Danian macrofauna not dispersed throughout the Greensand? If a Danian age for the Greensand is assumed, this could be expected. By contrast, the most macrofauna considered as Danian were recorded from around the phosphatic layer, forming patchy occurrences. How can one explain the presence of mixed upper Maastrichtian faunal assemblages from different (deep and shallow) biotopes within the Greensand and phosphatic layer (cf. Krach, 1981)? The same is true for the deep and shallow marine sponge assemblages mixed together in the phosphatic layer (ŚwierczewskaGładysz and Olszewska-Nejbert, 2006). How can one explain that within the sponge assemblage from the Greensand and phosphatic layer, solely Maastrichtian forms were recognized (Świerczewska-Gładysz and Olszewska-Nejbert, 2006)? These drawbacks can easily be avoided if a Maastrichtian age is accepted for the Greensand.

\section{K-PG BOUNDARY AND BASAL SIWAK [UNIT VI]}

We place the K-Pg boundary at the top of the phosphatic layer, thus at the base of the Siwak unit (Figs. 10 and 11) for the following reasons.

The foraminifera species, especially the massive bloom of Globoconusa daubjergensis, which start just above the phosphatic layer, indicate (Figs. 3 and 10) a very early Danian age, i.e. the standard foraminiferal $\mathrm{P} \alpha$ Zone (Fig. 5; see Olsson et al., 1999; Wade et al., 2011) or P1a Zone (Fig. 5; see Keller et al., 1995, 2002, 2008, 2012; Punekar et al., 2014a, b). This species constitutes $\sim 45 \%$ just above $(3-5 \mathrm{~cm})$ the top of the phosphatic layer, rising to $\sim 70 \%$ a dozen or so centimeters higher.

According to the upper Maastrichtian-Danian global zonations (e.g., Hansen, 1977; Powell, 1992; Williams et al., 2004), Carpatella cornuta was considered to be the earliest Danian marker. However, more recent papers by Slimani and Toufiq (2013) and Açıkalın et al. (2015) discredit Carpatella cornuta as a reliable biomarker for the definition of the K-Pg boundary since its FO is slightly younger. Senoniasphaera inornata, consistently present in sample B-5, indicates equally well a lowermost Danian age. In most zonal schemes, its FO corresponds to the lowermost Danian (Brinkhuis et al., 1998; Williams et al., 2004; Slimani et al., 2010; Slimani and Toufiq, 2013; Açıkalın et al., 2015).

An additional age determination of the Siwak unit can be derived from the co-occurrence of Carpatella cornuta and Palynodinium grallator in sample B-5, thus from directly above the phosphatic layer (Figs. 5 and 10). The LO of the latter species is placed within the lowermost Danian, as is the FO of the former one (Williams et al, 2004; Slimani and Toufiq, 2013; Açıkalın et al., 2015). This again suggests a lowermost Danian age for the lowermost portion of the Siwak (Figs. 5 and 10).

Up to now, the age of the Siwak [unit VI] has been variously interpreted, being regarded as Danian or even Montian in age (for a review see Machalski and Walaszczyk, 1987; Machalski 1998). Hansen et al. (1989), based on remagnetization above the phosphatic layer and dinoflagellate cysts, in addition to the postulated previous presence of an equivalent of the Cerithium Limestone based on infills in belemnite alveoli, considered the basal Siwak as being of lower, albeit not lowest Danian age. This concept has been adopted in all subsequently papers (Żarski et al., 1998; Machalski, 1998, 2005a, b, 2012; Świer-
czewska-Gładysz and Olszewska-Nejbert, 2006; Racki et al., 2011; Machalski et al., 2016). Despite extensive fieldwork at Nasiłów, checking hundreds of belemnite alveoli, nothing resembling the Cerithium Limestone has been found by us. Machalski and Jagt (2018) denied the presence in the Nasiłów area of an equivalent of the Danian Cerithium Limestone, postulated to be formerly present and now gone (cf. Hansen et al., 1989; Machalski, 1998).

Therefore, in the light of the new biostratigraphic data, these formed interpretations can no longer be upheld and the time gap, if any, is restricted currently to the PO foraminiferal zone only (Figs. 5, 9 and 10). This indicates a much shorter duration of the hiatus than postulated previously and makes the Nasiłów section one of the most complete K-Pg boundary sites in this part of Europe, one which includes diverse Cretaceous and Paleogene evidence.

\section{CONCLUSIONS}

Based on the results described above, the six lithological units of the Nasiłów section represent age assignments as follows:

1. The Kazimierz Opoka [unit I] belongs to the Belemnella kazimiroviensis belemnite Zone, the Hoploscaphites constrictus crassus ammonite Zone, the $P$. grallator dinoflagellate Zone, and the foraminiferal assemblage Zone XII of Dubicka and Peryt (2012). All indicate its upper Maastrichtian age (Fig. 11).

2. The hardened limestone [unit II] can be safely placed into the $B$. kazimiroviensis belemnite Zone, the $H$. c . crassus ammonite Zone, the $T$. pelagica Subzone of the $P$. grallator dinoflagellate Zone, and the foraminiferal assemblage Zone XII. All indicate an uppermost Maastrichtian age (Fig. 11).

3. The marly chalk [unit III] can be placed into the $B$. kazimiroviensis belemnite Zone, the upper part of the $H$. constrictus crassus or $H$. c. johnjagti ammonite Zone, the $T$. pelagica Subzone of the $P$. grallator dinoflagellate Zone, and the upper part of the regional foraminiferal assemblage Zone XIII of Dubicka and Peryt (2012). All indicate its terminal Maastrichtian age (Fig. 11).

4. The Greensand [unit IV], together with the overlying phosphatic layer [unit V], although clearly reworked, contains elements from the very last levels of the Maastrichtian (including those not known from underlying units), thus from the $B$. kazimiroviensis belemnite Zone, the $H$. c. crassus and $H$. c. johnjagti ammonite Zones, the $T$. pelagica Subzone of the $P$. grallator dinoflagellate Zone, and the upper part of the regional foraminiferal assemblage Zone XIII. All indicate its very terminal Maastrichtian age (Fig. 11).

5. The lowermost part of the Siwak [unit VI], thus the unit starting from the phosphatic layer upwards, represents foraminiferal $\mathrm{P} \alpha$, or alternatively $\mathrm{P} 1 \mathrm{a}$ Zone indicating its lower Danian age, with most likely only the P0 foraminiferal Zone missing.

The K-Pg boundary at Nasiłów is interpreted here at the top of the phosphatic layer. Although the physical break is evident, the biostratigraphic data show that the K-Pg boundary interval at Nasilów is almost complete within the limits of biostratigraphic resolution, including the presence of terminal Maastrichtian and lower Danian microfossils.

The physical gap in the critical interval is connected with an erosional event, which affected at least part of the very terminal Maastrichtian deposits represented by the grey marly chalk, the remnants of which are still preserved within pockets in the un- 
even surface of the hardground and as shards dispersed within the Greensand. There are also remnants of possibly even younger deposits than the marly chalk, which is inferred from the terminal Maastrichtian dinoflagellate cyst species Glaphyrocyata perforata known from the Greensand and not known from e.g. the grey marly chalk and underlying deposits. This time gap is, however, below the available biostratigraphic resolution.

The new palaeomagnetic investigations showed that no stable primary or secondary magnetic direction could be identified in the samples analysed; therefore, magnetostratigraphy is found to be an unreliable stratigraphic tool for the Nasiłów section. Accordingly, the palaeomagnetic data do not prove the remagnetization at the boundary interval, an interpretation in contrast with previous research and in line with the new biostratigraphic data (foraminifers and dinoflagellate cysts). The presence and duration of the hiatal event covering the uppermost Maastrichtian and lowermost Danian, such as predicted based on the previous palaeomagnetic data, and supposed remagnetization in the critical interval, cannot be demonstrated and remains in conflict with the new biostratigraphic results we obtained.

The "iridium layer", so far not recognized in the Nasiłów section, most likely covered the Greensand just after post-Cretaceous times and subsequently diffused downwards or was diluted by winnowing by bottom currents. The presence of iridium fall-out is indicated by small enrichments in Ir-PI and REEs within the Greensand (Hansen et al., 1989). Such behaviour, i.e. downwards remobilization of Ir-PI REEs, has been recently demonstrated in sections on both sides of the Atlantic Ocean, including the Lechówka section in Eastern Poland, 100 km east of Nasiłów (Racki et al., 2011; Machalski et al., 2016) and on the New Jersey Atlantic Coastal Plain (Landman et al., 2012, 2014). The former presence of an iridium layer at Nasiłów is even more evident if taking into consideration that, in the Lechówka section, both the K-Pg geochemical spike and spherules have been recently recognized (Racki et al., 2011; Brachaniec et al., 2014; Machalski et al., 2016). The lack of a dark organic-rich $\mathrm{K}-\mathrm{Pg}$ boundary clay enriched in iridium and other REEs, which usually corresponds to foraminiferal PO Zone known in more complete $\mathrm{K}-\mathrm{Pg}$ sections worldwide (e.g., Molina et al., 2006, 2009), is the most likely cause of why the P0 zone has not been detected in the Nasiłów section.

The new biostratigraphic and palaeomagnetic data described herein indicate an almost complete record of the Nasiłów succession and suggest the terminal Maastrichtian age of the Greensand. In consequence, a new sedimentological scenario may be envisaged. It should explain the development of the anomalous Greensand and the presence within it of mixed macrofaunal assemblages coming from different, deep, and shallow biotopes, thus coming from different parts of the basin, in addition to, not infrequently, inherently contradictory taphonomic data. This scenario will be published elsewhere.

Acknowledgements. Thanks go to members of the ExTerra Students Scientific Club for help during the fieldwork, particularly B. Dabrowska, B. Gościmski, M. Kulczyńska, F. Owczarek, M. Surowski, M. Żurawski and others. B. Waksmundzki, I. Walaszczyk, W. Kozłowski (all from the University of Warsaw), K. Wójcik (PGI-PIB), N. Keutgen (Vienna), P. Gedl and D. Peryt (both from the Polish Academy of Sciences) are thanked for stimulating discussions during different stages of the manuscript. The research has been sponsored by the Faculty of Geology of the University of Warsaw. Part of the research has been additionally supported by the Polish National Science Centre [NCN]; grant number UMO-2013/09/B/ST10/01912.

\section{REFERENCES}

Abdel-Gawad, G.I., 1986. Maastrichtian non-cephalopod mollusks (Scaphopoda, Gastropoda and Bivalvia) of the Middle Vistula Valley, Central Poland. Acta Geologica Polonica, 36: 69-224.

Abramovich, S., Almogi-Labin, A., Benjamini, C., 1998. Decline of the Maastrichtian pelagic ecosystem based on planktic foraminiferal assemblage changes: implications for the terminal Cretaceous faunal crisis. Geology, 26: 63-66.

Açıkalın, S., Vellekoop, J., Ocakoğlu, F., Yılmaz, I.Ö., Smit, J., Altıner, S.Ö., Goderis, S., Vonhof, H., Speijer, R.P., Woelders, L., Fornaciari, E., Brinkhuis, H., 2015. Geochemical and palaeontological characterization of a new K-Pg Boundary locality from the Northern branch of the Neo-Tethys: Mudurnu-Göynük Basin, NW Turkey. Cretaceous Research, 52: 251-267.

Benson, D.G., 1976. Dinoflagellate taxonomy and biostratigraphy at the Cretaceous-Tertiary boundary, Round Bay, Maryland. Tulane Studies in Geology and Paleontology, 12: 169-233.

Błaszkiewicz, A., 1980. Campanian and Maastrichtian ammonites of the Middle Vistula River Valley, Poland: a stratigraphic-palaeontological study. Prace Instytutu Geologicznego, 92: 3-63.

Brachaniec, T., Karwowski, Ł., Szopa, K., 2014. Spherules associated with the Cretaceous-Paleogene boundary in Poland. Acta Geologica Polonica, 64: 99-108.

Brinkhuis, H., Zachariasse, W.J., 1988. Dinoflagellate cysts, sea level changes and planktonic foraminifers across the $\mathrm{K}-\mathrm{T}$ boundary at El Haria Northwest Tunisia. Marine Micropaleontology, 13: 153-191.

Brinkhuis, H., Bujak, J.P., Smit, J., Versteegh, G.J.M., Visscher, H., 1998. Dinoflagellate-based sea surface temperature reconstructions across the Cretaceous-Tertiary boundary. Palaeogeography, Palaeoclimatology, Palaeoecology, 141: 67-83.

Dekkers, M.J., 1988. Magnetic properties of natural pyrrohotite. Part I: behaviour of initial susceptibility and saturation-magnetization-related rock-magnetic parameters in a grain-size dependent framework. Physics of the Earth and Planetary Interiors, 52: 376-393.

Dubicka, Z., Peryt, D., 2012. Latest Campanian and Maastrichtian palaeoenvironmental changes: implications from an epicontinental sea (SE Poland and western Ukraine). Cretaceous Research, 37: 272-284.

Gubbins, D., Herrero-Bervera, E., (eds.), 2007. Encyclopedia of Geomagnetism and Paleomagnetism. Berlin, Springer.

Hansen, J.M., 1977. Dinoflagellate stratigraphy and echinoid distribution in Upper Maastrichtian and Danian deposits from Denmark. Bulletin of the Geological Society of Denmark, 26: 1-26.

Hansen, H.J., Rasmussen, K.A., Gwozdz, R., Hansen, J.M., Radwański, A., 1989. The Cretaceous/Tertiary boundary in Central Poland. Acta Geologica Polonica, 39: 1-12.

Keller, G., Abramovich, S., 2009. Lilliput effect in Late Maastrichtian planktic foraminifera: response to environmental 
stress. Palaeogeography, Palaeoclimatology, Palaeoecology, 284: 47-62.

Keller, G., Li, L., MacLeod, N., 1995. The Cretaceous/Tertiary boundary stratotype section at El Kef, Tunisia: how catastrophic was the mass extinction? Palaeogeography, Palaeoclimatology, Palaeoecology, 119: 221-254.

Keller, G., Adatte, T., Stinnesbeck, W., Luciani, V., Karoui, N., Zaghbib-Turki, D., 2002. Paleoecology of the Cretaceous-Tertiary mass extinction in planktic foraminifera. Palaeogeography, Palaeoclimatology, Palaeoecology, 178: 257-298.

Keller, G., Adatte, T., Gardin, S., Bartolini, A., Bajpai, S., 2008. Main Deccan volcanism phase ends near the K-T boundary: evidence from the Krishna-Godavari Basin, SE India. Earth and Planetary Science Letters, 268: 293-311.

Keller, G., Adatte, T., Bhowmickc, P.K., Upadhyayc, H., Davec, A., Reddy, A.N., Jaiprakash, B.C., 2012. Nature and timing of extinctions in Cretaceous-Tertiary planktic foraminifera preserved in Deccan intertrappean sediments of the KrishnaGodavari Basin, India. Earth and Planetary Science Letters, 341-344: 211-221

Kennedy, W.J., Garrison, R.E., 1975. Morphology and genesis of nodular chalks and hardgrounds in the Upper Cretaceous of southern England. Sedimentology, 22: 311-386.

Keutgen, N., Remin, Z., Jagt, J.M.W., 2017. The late Maastrichtian Belemnella kazimiroviensis group (Cephalopoda, Coleoidea) in the Middle Vistula valley (Poland) and the Maastricht area (the Netherlands, Belgium) - paleobiological and stratigraphic implications. Palaeontologia Electronica, 20.2.37A(2017): 1-29.

Krach, W., 1974. Biostratigraphy of the Palaeogene in the middle Vistula region on the basis of mollusc macrofauna (in Polish with English summary). Biuletyn Instytutu Geologicznego, 281: 49-58.

Krach, W., 1981. Paleocene fauna and stratigraphy of the middle Vistula River, Poland (in Polish with English summary). Studia Geologica Polonica, 71: 1-80.

Landman, N.H., Garb, M.P., Rovelli, R., Ebel, D.S., Edwards, L.E., 2012. Short term survival of ammonites in New Jersey after the end Cretaceous bolide impact. Acta Palaeontologica Polonica, 57: 703-715

Landman, N.H., Goolaerts, S., Jagt, J.W.M., Jagt-Yazykova, E.A., Machalski, M., Yacobucci, M., 2014. Ammonite extinction and nautilid survival at the end of the Cretaceous. Geology, 42: $707-710$

Lowrie, W., 1990. Identification of ferromagnetic minerals in a rock by coercivity and unblocking temperature properties. Geophysical Research Letters, 17: 159-162.

Machalski, M., 1998. The Cretaceous-Tertiary boundary in Central Poland (in Polish with English summary). Przegląd Geologiczny, 46: 1153-1161.

Machalski, M., 2005a. The youngest Maastrichtian ammonite faunas from Poland and their dating by scaphitids. Cretaceous $\mathrm{Re}-$ search, 26: 813-836.

Machalski, M., 2005b. Late Maastrichtian and earliest Danian scaphitid ammonites from central Europe: taxonomy, evolution, and extinction. Acta Palaeontologica Polonica, 50: 653-696.

Machalski, M., 2012. A new ammonite zonation for the Maastrichtian Stage in Poland. In: The Maastrichtian stage; the current concept (eds. J.W.M. Jagt and E.A. Jagt-Yazykova): 40-44. Natuurhistorisch Museum Maastricht, Netherlands.

Machalski, M., Walaszczyk, I., 1987. Faunal condensation and mixing in the uppermost Maastrichtian/Danian Greensand (Middle Vistula Valley, central Poland). Acta Geologica Polonica, 37: 75-91.

Machalski, M., Walaszczyk, I., 1988. The youngest (uppermost Maastrichtian) ammonites in the middle Vistula Valley, Central Poland. Bulletin of the Polish Academy of Sciences, Earth Sciences, 36: 67-70.

Machalski, M., Vellekoop, J., Dubicka, Z., Peryt, D., Harasimiuk, M., 2016. Late Maastrichtian cephalopods, dinoflagellate cysts and foraminifera from the Cretaceous-Paleogene succession at Lechówka, southeast Poland: stratigraphic and environmental implications. Cretaceous Research, 57: 208-227.

Molina, E., Alegret, L., Arenillas, I., Arz, J.A., Gallala, N., Herdenbol, J., von Salis, K., Sterbaut, E., Vanderberghe, N., Zaghbib-Turki, D., 2006. The Global Stratotype Section and Point for the base of the Danian Stage (Paleocene, Paleogene, "Tertiary", Cenozoic) at El Kef, Tunisia - Original definition and revision. Episodes, 29: 263-273.

Molina, E., Alegret, L., Arenillas, I., Arz, J.A., Gallala, N., Grajales-Nishimura, J.M., Murillo-Muneton, G., ZaghbibTurki, D., 2009. The Global Boundary Stratotype Section and Point for the base of the Danian Stage (Paleocene, Paleogene," Tertiary", Cenozoic): auxiliary sections and correlation. Episodes, 32: 84-95.

Olsson, R.K., Hemleben, C., Berggren W., Huber, C., 1999. Atlas of Paleocene Planktonic Foramnifera. Smithsonian Contributions to Paleobiology, 85: 1-252.

Pardo, A., Keller, G., 2008. Biotic effects of environmental catastrophes at the end of the Cretaceous: Guembelitria and Heterohelix blooms. Cretaceous Research, 29: 1058-1073.

Plasota, T., Nawrocki, J., Walaszczyk, I., 2015. Magnetostratigraphy of the Campanian/Maastrichtian boundary succeson from the Middle Vistula River section, Central Poland. Geological Quarterly, 59 (4): 831-842.

Powell, A.J., 1992. Dinoflagellate cysts of the Tertiary System. In: A Stratigraphic Index of Dinoflagellate Cysts (ed A.J. Powell): 155-252. Chapman \& Hall, London.

Pożaryska, K., 1952. The sedimentological problems of Upper Maastrichtian and Danian of the Puławy environment (Middle Vistula) (in Polish with English summary). Biuletyn Państwowego Instytutu Geologicznego, 81: 1-104.

Pożaryska, K., 1965. Foraminifera and biostratigraphy of the Danian and Montian in Poland. Palaeontologica Polonica, 14: 1-156.

Pożaryska, K., 1967. Cretaceous - Tertiary transition beds in Poland (except for the Carpathians) (in Polish with English summary). Kwartalnik Geologiczny, 11 (3): 661-672.

Pożaryski, W., 1974. Budowa Geologiczna Polski, T. IV, Tektonika, cz. 1, Niż Polski (in Polish). Wyd. Geol., Warszawa.

Punekar, J., Matteo, P., Keller, G., 2014a. Effects of Deccan volcanism on paleoenvironment and planktic foraminifera: a global survey. GSA Special Paper, 505: 91-117.

Punekar, J., Keller, G., Khozyem, H., Hamming, C., Adatte, T., Tantawy, A.A., Spangenberg, J.E., 2014b. Late Maastrihtianearly Danian high-stress evvironments and delayed recovery linked to Decan volcanism. Cretaceous Research, 49: 1-20.

Radwański, A., 1985. Cretaceous. In: Field-Guide to Geological Excursion to Poland (eds. Z. Bełka, B.A. Matyja and A. Radwański): 227-264. University of Warsaw, Warszawa.

Radwański, A., 1996. The predation upon, and the extinction of, the latest Maastrichtian populations of the ammonite species Hoploscaphites constrictus (J. Sowerby, 1817) from the Middle Vistula Valley, Central Poland. Acta Geologica Polonica, 46: 117-135.

Racki, G., Machalski, M., Koeberl, C., Harasimiuk, M., 2011. The weathering-modified iridium record of a new Cretaceous-Palaeogene site at Lechówka near Chełm, SE Poland, and its palaeobiologic implications. Acta Palaeontologica Polonica, 56: 205-215.

Remin, Z., Dubicka, Z., Kozłowska, A., Kuchta, B., 2012. A new method of rock disintegration and foraminiferal extraction with the use of liquid nitrogen [LN2]. Do conventional methods lead to biased paleoecological and paleoenviromental interpretations? Marine Micropaleontology, 86-87: 11-14.

Schulte, P., Alegret, L., Arenillas, I., Arz, J.A., Barton, P.J., Brown, P.R., Bralower, T.J., Christeson, G.L., Claeys, P., Cockell, C.S., Collins, G.S., Deutsch, A., Goldin, T.J., Goto, K., Grajales-Nishimura, J.M., Grieve, R.A.F., Gulick, S.P.S., Johnson, K.R., Kiessling, W., Koeberl, C., Kring, D.A., Macleod, K.G., Matsui, T., Melosh, J., Montanari, A., Morgan, 
J.V., Neal, C.R., Nichols, D.J., Norris, R.D., Pierazo, E., Ravizza, G., Rebolledo-Vieyra, M., Reimond,W.U., Robin, E., Salge, T., Speijer, R.P., Sweet, A.R., Urrutia-Fucugauchi, J., Vajda, V., Whalen, M.T., Willumsen, P.S., 2010. The Chicxulub asteroid impact and mass extinction at the CretaceousPaleogene boundary. Science, 327: 1214-1218.

Schiøler, P., Wilson, G.J., 1993. Maastrichtian dinofagellate zonation in the Dan field, Danish North Sea. Review of Paleobotany and Palynology, 78: 321-351.

Schiøler, P., Brinkhuis, H., Roncaglia, L., Wilson, G.J., 1997. Dinoflagellate biostratigraphy and sequence stratigraphy of the type Maastrichtien (Upper Cretaceous), Enci Quarry, The Netherlands. Marine Micropaleontology, 31: 65-95.

Schoene, B., Samperton, K.M., Eddy, M.P., Keller, G., Adatte, T., Bowring, S.A., Khadri, S.F.R., Gertsch, B., 2015. U-Pb geochronology of the Deccan Traps and relation to the end-Cretaceous mass extinction. Science, 347: 182-184.

Silimani, H., Louwye, S., Toufiq, A., 2010. Dinoflagellate cysts from the Cretaceous-Paleogene boundary at Ouled Haddou, southeastern Rif, Morocco: biostratigraphy, paleoenvironments and paleobiogeography. Palynology, 34: 90-124.

Slimani, H., Toufiq, A., 2013. A Cretaceous-Palaeogene boundary geological site, revealed by planktic foraminifera and dinoflagellate cysts, at Ouled Haddou, eastern external Rif Chain, Morocco. Journal of African Earth Sciences, 88: 38-52.

Świerczewska-Gładysz, E., Olszewska-Nejbert, D., 2006. The origin of phosphatized sponges from the Danian glauconitic sand- stone from Nasiłów (central Poland, Vistula River valley) (in Polish with English summary). Przegląd Geologiczny, 54: 710-719.

Tantawy, A.A., Keller, G., Pardo, A., 2009. Late Maastrichtian volcanism in the Indian Ocean: effects on calcareous nannofossils and planktic foraminifera. Palaeogeography, Palaeoclimatology, Palaeoecology, 284: 63-84.

Toon, O.B., Zahnle, K., Morrison, D., Turco, R.P., Covey, C., 1997. Environmental perturbations caused by the impacts of asteroids and comets. Reviews of Geophysics, 35: 41-78.

Wade, B.S., Pearson, P.N., Berggren, W.A., Pälike, H., 2011. Review and revision of Cenozoic tropical planktonic foraminiferal biostratigraphy and calibration to the geomagnetic polarity and astronomical time scale. Earth-Science Reviews, 104: 111-142.

Walaszczyk, I., Dubicka, Z., Olszewska-Nejbert, D., Remin, Z. 2016. Integrated biostratigraphy of the Santonian through Maastrichtian (Upper Cretaceous) of extra-Carpathian Poland. Acta Geologica Polonica, 66: 313-350.

Williams, G.L., Brinkhuis, H., Pearce, M.A., Fensome, R.A., Weegink, J.W., 2004. Southern Ocean and global dinoflagellate cyst events compared: Index events for the Late Cretaceous-Neogene. Proceedings of the Ocean Drilling Program, Scientific Results, 189: 1-98.

Żarski, M., Jakubowski, G., Gawor-Biedowa, E., 1998. The first Polish find of a Lower Paleocene crocodile Thoracosaurus Leidy, 1852; geological and palaeontological description. Geological Quarterly, 42 (2): 141-160. 